OPEN ACCESS

Edited by: Soldevila Gloria, National Autonomous University of Mexico, Mexico

Reviewed by: Marit Inngjerdingen, Oslo University Hospital, Norway Geoffrey William Mccaughan, University of Sydney, Australia

Patrick Jerome Bertolino,

University of Sydney, Australia

*Correspondence:

Ping Zhu

tanganqier@163.com

Xiao-Kang Li

ri-k@ncchd.go.jp

tThese authors have contributed equally to this work

Specialty section: This article was submitted to Alloimmunity and Transplantation, a section of the journal Frontiers in Immunology

Received: 21 February 2020 Accepted: 14 May 2020

Published: 12 June 2020

Citation:

Jiang Y, Que W, Zhu P and Li X-K (2020) The Role of Diverse Liver Cells

in Liver Transplantation Tolerance.

Front. Immunol. 11:1203.

doi: 10.3389/fimmu.2020.01203

\section{The Role of Diverse Liver Cells in Liver Transplantation Tolerance}

\author{
Yanzhi Jiang ${ }^{1,2 \dagger}$, Weitao Que ${ }^{1 \dagger}$, Ping Zhu ${ }^{2 *}$ and Xiao-Kang $\mathrm{Li}^{1 *}$ \\ ${ }^{1}$ Division of Transplantation Immunology, National Research Institute for Child Health and Development, Tokyo, Japan, \\ ${ }^{2}$ Guangdong Cardiovascular Institute, Guangdong Provincial People's Hospital, Guangdong Academy of Medical Sciences, \\ Guangzhou, China
}

Liver transplantation is the ideal treatment approach for a variety of end-stage liver diseases. However, life-long, systemic immunosuppressive treatment after transplantation is required to prevent rejection and graft loss, which is associated with severe side effects, although liver allograft is considered more tolerogenic. Therefore, understanding the mechanism underlying the unique immunologically privileged liver organ is valuable for transplantation management and autoimmune disease treatment. The unique hepatic acinus anatomy and a complex cellular network constitute the immunosuppressive hepatic microenvironment, which are responsible for the tolerogenic properties of the liver. The hepatic microenvironment contains a variety of hepatic-resident immobile non-professional antigen-presenting cells, including hepatocytes, liver sinusoidal endothelial cells, Kupffer cells, and hepatic stellate cells, that are insufficient to optimally prime T cells locally and lead to the removal of alloreactive $T$ cells due to the low expression of major histocompatibility complex ( $\mathrm{MHC}$ ) molecules, costimulatory molecules and proinflammatory cytokines but a rather high expression of coinhibitory molecules and anti-inflammatory cytokines. Hepatic dendritic cells (DCs) are generally immature and less immunogenic than splenic DCs and are also ineffective in priming naïve allogeneic $T$ cells via the direct recognition pathway in recipient secondary lymphoid organs. Although natural killer cells and natural killer T cells are reportedly associated with liver tolerance, their roles in liver transplantation are multifaceted and need to be further clarified. Under these circumstances, $T$ cells are prone to clonal deletion, clonal anergy and exhaustion, eventually leading to tolerance. Other proposed liver tolerance mechanisms, such as soluble donor MHC class I molecules, passenger leukocytes theory and a high-load antigen effect, have also been addressed. We herein comprehensively review the current evidence implicating the tolerogenic properties of diverse liver cells in liver transplantation tolerance.

Keywords: allograft, hepatic microenvironment, liver transplantation, $\mathrm{T}$ cell, tolerance 


\section{INTRODUCTION}

Liver transplantation is the ideal therapeutic approach for a variety of end-stage liver diseases. However, life-long, systemic immunosuppressive treatment is required after transplantation to prevent rejection and graft loss, which is associated with high costs and severe side effects, including infections and malignancy $(1,2)$. From an immunological standpoint, a liver allograft is more tolerogenic than such grafts for other solid organs, like the heart, kidney, and lung. Spontaneous liver allograft acceptance without the need for immunosuppression has been observed in multiple experimental animal transplantation models (3-5). In clinical practice, liver allografts show a lower rejection rate than such grafts of other solid organs, and around half of carefully selected liver transplant recipients are able to be completely weaned from immunosuppression, which rarely occurs in cases of other organ transplantation (5-7). Furthermore, liver allografts are associated with tolerance induction for other simultaneous or sequentially transplanted organs in human and animal models, indicating that the liver can induce systemic tolerance (8-12). Therefore, understanding the mechanisms underlying the unique immunologically privileged liver organs is valuable for transplantation management and autoimmune disease treatment.

The liver is the central metabolic organ responsible for metabolism, nutrient storage and detoxification and also functions as an immunological organ. To fulfill its multifaceted functions, the liver comprises repetitive functional units formed by a myriad of cell types. The functional unit, known as the hepatic acinus, consists of an irregular-shaped, roughly ellipsoidal mass of parenchymal cells grouped around the terminal branches of hepatic arterioles and portal venules just as they anastomose into sinusoids (13, 14). The liver sinusoids are lined by a thin layer of fenestrated liver sinusoidal endothelial cells (LSECs) and lack organized basal lamina, which facilitate the passage of blood plasma to the underlying hepatocytes. Microvilli of hepatocytes extend into the space of Disse, existing between sinusoids and hepatocytes and exerting metabolic functions.

The liver receives a dual blood supply from the hepatic artery and portal vein. The arterial blood is oxygenated, while the venous blood is rich in pathogens, toxins and harmless dietary antigens from the gut; the liver therefore faces constant immunologic challenges. The arterial and portal-venous blood undergoes confluence and runs through the liver sinusoids toward the central vein or terminal hepatic venules at a low speed, which facilitates the uptake of gut-derived content by liver cells. As an important barrier between the gut and the circulation, the liver interstitium is highly enriched in both innate and adaptive immune cells, such as LSECs, Kupffer cells (KCs), dendritic cells (DCs), hepatic stellate cells (HSCs), natural killer (NK) cells, natural killer T (NKT) cells, and T cells. These cells contribute to the formation of a local tolerogenic milieu that ignores most harmless self and foreign antigens while retaining immunity to pathogens in order to maintain immune system homeostasis. The overall tolerogenic properties of the liver are markedly manifested in the era of transplantation.

We herein comprehensively review the current evidence implicating the tolerogenic properties of diverse liver cells in liver transplantation tolerance (Figure 1).

\section{HEPATIC PARENCHYMA MEDIATED TOLERANCE EFFECTS}

\section{Role of Hepatocytes}

Approximately $60-80 \%$ of the total liver cell population is composed of parenchymal hepatocytes, which robustly express and secrete large amounts of proteins involved in metabolism, glycogen synthesis and toxin decomposition (15, 16). There is growing evidence showing that hepatocytes are involved in immunity by expressing immune receptors, such as pattern recognition receptors, major histocompatibility complex (MHC) and adhesion molecules (16-18). The special physiological and immunological functions of hepatocytes and their complex interaction with non-substantive cells of the liver have a significant impact on the host's immune system and can promote immune tolerance in cases of liver transplantation.

The microvilli of hepatocytes can make contact with the filamentous pseudopodia of $\mathrm{T}$ cells across the endothelial fenestrations, thereby presenting antigens to $\mathrm{T}$ cells $(19,20)$. Hepatocytes continuously express MHC class I and are capable of presenting antigens to $\mathrm{CD} 8^{+} \mathrm{T}$ cells to trigger $\mathrm{CD}^{+} \mathrm{T}$ cell activation and proliferation (21). Hepatocytes can alternatively present antigens to $\mathrm{CD}^{+} \mathrm{T}$ cells through cross-presentation, which is controlled by a specific molecular chaperone called collectrin in the endoplasmic reticulum-Golgi intermediate chamber (22). However, due to the lack of necessary survival factors, $\mathrm{CD}^{+} \mathrm{T}$ cells activated by hepatocytes quickly undergo apoptosis through BCL-2-interacting mediator (bim)- and caspase-dependent apoptosis after transient proliferation and cytotoxic T lymphocyte (CTL) function (20, 23). Hepatocytes can also actively induce $\mathrm{CD} 8^{+} \mathrm{T}$ cell apoptosis via the FAS or TNF pathway (24). Furthermore, hepatocytes primed $\mathrm{CD}^{+} \mathrm{T}$ cells produce abundant amounts of interleukin (IL)-10 in the absence of IFN- $\beta$-producing NKT cells co-activated by the same hepatocytes, thus exerting immunosuppressive function (25). When confronted with an inflammatory response, hepatocytes can be induced to express MHC class II and present antigens to $\mathrm{CD}^{+} \mathrm{T}$ cells $(26,27)$. Hepatocytes were found to mediate the Th2 differentiation of uncommitted $\mathrm{CD} 4^{+} \mathrm{T}$ cells and abrogate the capacity of established Th1 cells to secrete IFN- $\gamma$ (28). Interestingly, hepatocytes promote the conversion of $\mathrm{CD} 4^{+} \mathrm{T}$ cells into $\mathrm{CD}^{+}{ }^{+} \mathrm{CD} 25^{+}$Foxp $^{+}$regulatory $\mathrm{T}$ (Treg) cells and thus induce immune tolerance through the Notch signal pathway (29). Moreover, exosomes or paracrine factors secreted by hepatocytes can also be involved in immune tolerance by interacting with lymphocytes $(30,31)$.

In brief, hepatocytes regulate immune tolerance in liver transplantation directly and indirectly, and more studies in 


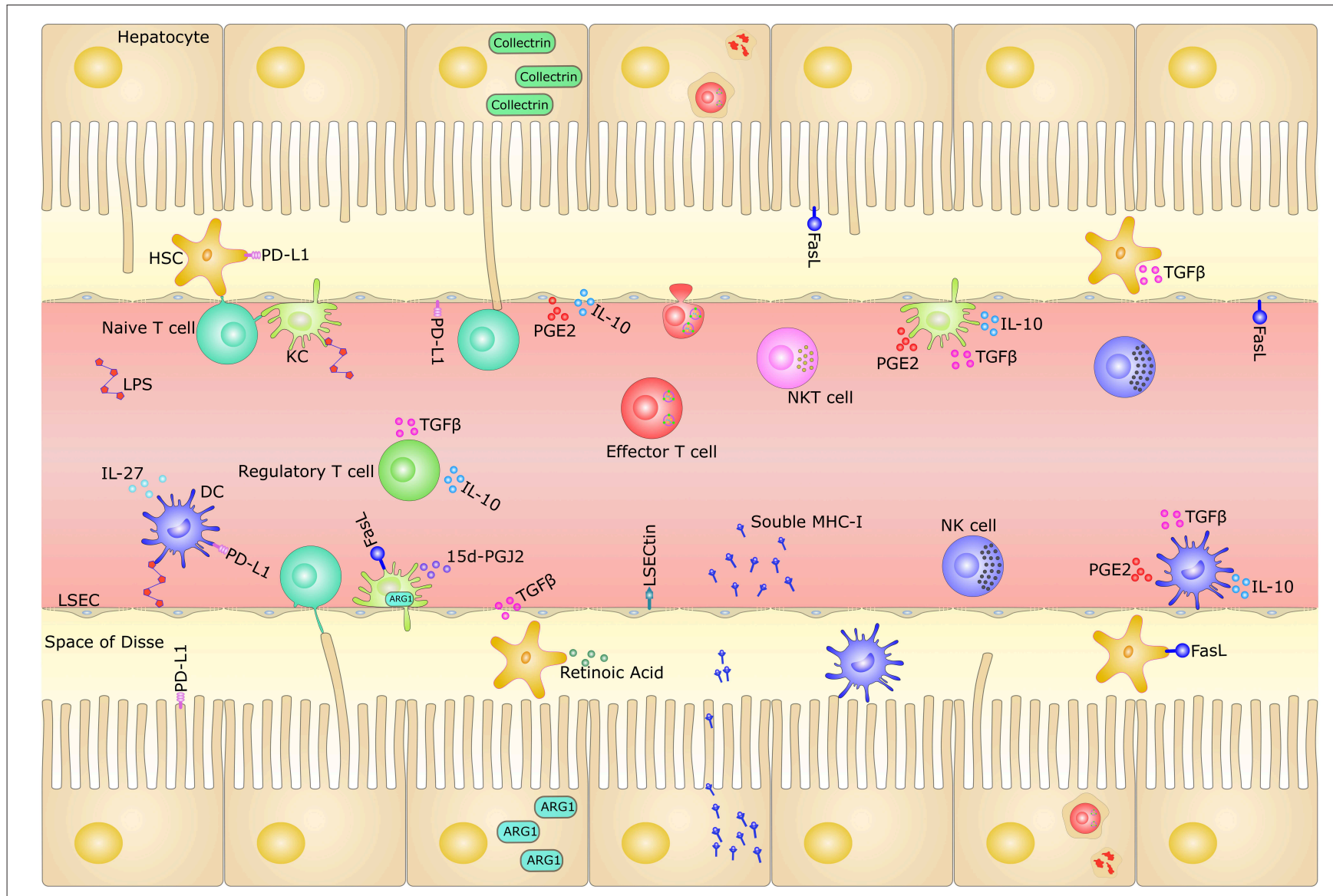

FIGURE 1 | Mechanisms of tolerogenic hepatic microenvironment. The liver sinusoids are lined by a thin layer of fenestrated LSECs and lack organized basal lamina, which facilitate the passage of blood plasma to the underlying hepatocytes. Microvilli of hepatocytes extend into the space of Disse, existing between sinusoids and hepatocytes. The oxygenated arterial and nutrient- rich portal-venous blood undergoes confluence and runs through the liver sinusoids, carrying pathogens, toxins and harmless dietary antigens from the gut. The liver is highly enriched in both innate and adaptive immune cells, such as LSECs, KCs, DCs, HSCs, NK cells, NKT cells, and T cells. The unique liver microenvironment, with its slow blood flow and fenestrated endothelium in the narrow hepatic sinusoids, permits the continuous functional interaction between circulating naive T cells and the diverse hepatic-resident immobile non-professional APCs, such as hepatocytes, LSECs, KCs, DCs, and HSCs. This makes the liver the only non-lymphoid organ that can prime naïve T cell locally. These cells contribute to the liver tolerance through direct cell-cell interaction signaling by surface inhibitory molecules, as well as immunosuppressive milieu through secretory factors. The hepatocytes could also release massive amounts of soluble MHC class I molecules and destroy activated CD8+ T cells through "suicidal emperipolesis" mechanism. HSC, hepatic stellate cell; LSEC, liver sinusoidal endothelial cell; DC, dendritic cell; NK, natural killer cell; NKT, natural killer T cell; KC, Kupffer cell; IL-10, interleukin (IL)-10; TGF- $\beta$, transforming growth factor (TGF)- $\beta$; LSECtin, LSEC C-type lectin; MHC-I, major histocompatibility complex class I; PD-L1, programmed death ligand 1; FasL, Fas ligand; LPS, lipopolysaccharide; IL-27, interleukin (IL)-27; 15d-PGJ2, 15-Deoxy-Delta-12,14-prostaglandin J2; ARG1, Arginase-1; APC, Antigen-presenting cell; PGE2, Prostaglandin E2.

the future are needed to clarify the mechanism underlying hepatocyte-mediated immune tolerance.

\section{THE INNATE IMMUNE TOLERANCE MECHANISMS}

\section{Role of LSECs}

LSECs constitute about $50 \%$ of non-parenchymal cells in the liver and line the hepatic sinusoids (16). Due to the special structure and abundant blood supply of hepatic sinusoids, LSECs filter out antigens in the blood and play a vital role in maintaining the homeostasis of the hepatic immune microenvironment (32). LSECs express a variety of recognition receptors and scavenger receptors to clear away pathogens in a non-specific manner thus to maintain immune homeostasis of the liver (33-36). In addition, LSECs express MHC class I and II to present antigens to $\mathrm{CD}^{+}$and $\mathrm{CD}^{+} \mathrm{T}$ cells, acting as important hepatic resident non-professional APCs $(32,34,37,38)$. On the other hand, LSECs collect MHC class I molecules from their neighbor cells for cross-presentation to CD8 ${ }^{+} \mathrm{T}$ cell (39).

LESCs primed naïve $\mathrm{CD} 4^{+} \mathrm{T}$ cells toward Treg differentiation and suppressed the Th1 and Th17 function via IL-10 and PD-1 signaling $(33,38,40)$. Studies have shown that LSECs promote the growth of IL-4-expressing Th2 cells and induce a mass of IL-10 secretion through the Notch pathway, thereby creating an immunosuppressive environment within the liver 


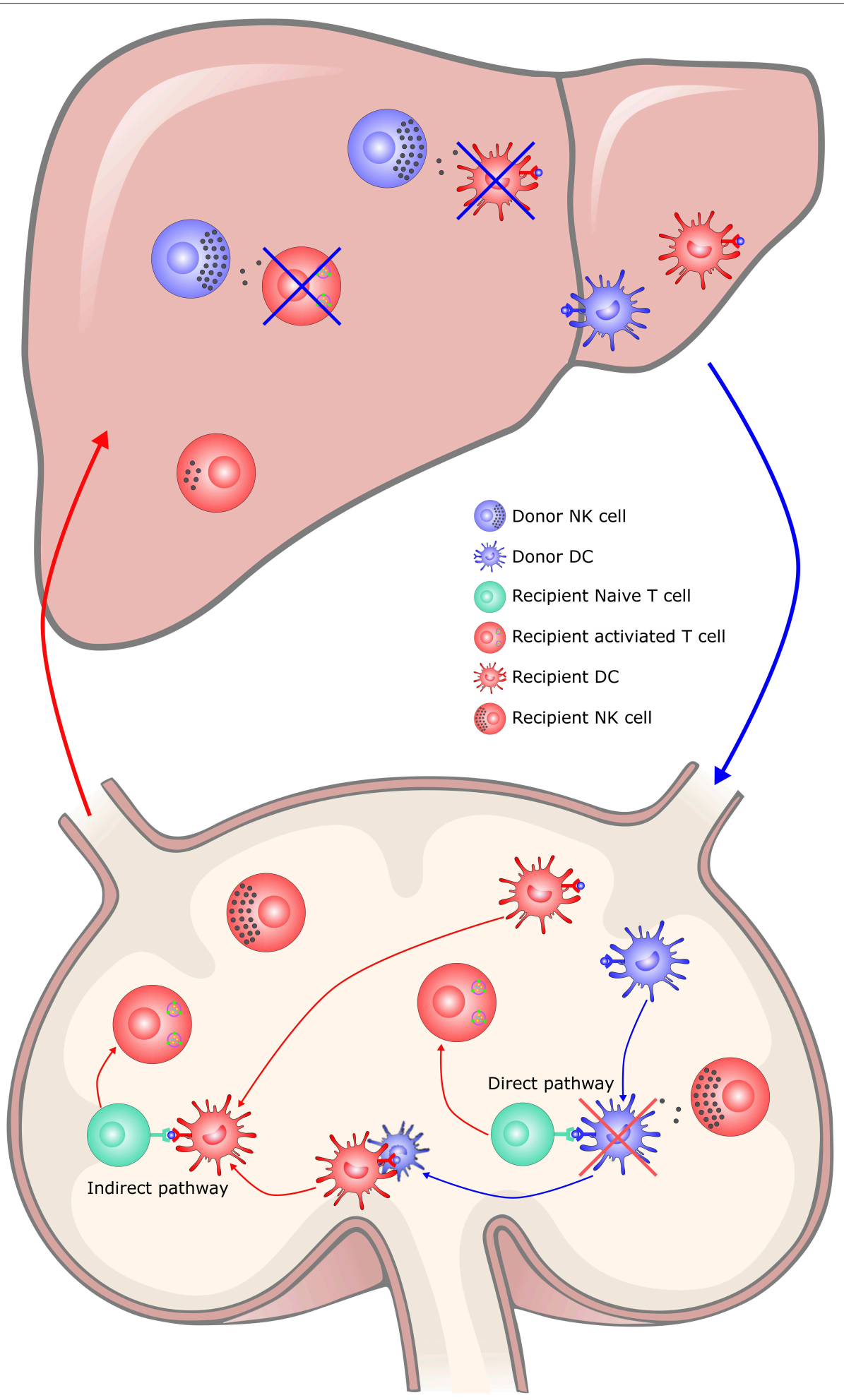

FIGURE 2 | The hypothesis of NK cells in liver transplantation tolerance. In the liver, donor hepatic NK cells promote tolerance, possibly by directly killing recipient immune cells including activated T cells and recipient immature DCs recruited to the allograft, which limited the immune rejection responses. Recipient NK cells would switch to a tolerant phenotype in the tolerogenic hepatic microenvironment. In the secondary lymphoid organs, recipient NK cells kill donor passenger DCs, thereby limiting the activation of T cells by the direct pathway, but favoring the indirect pathway-primed alloreactive T cell response, which contributes to tolerance induction. DC, dendritic cell; NK, natural killer cell; APC, Antigen-presenting cell. 


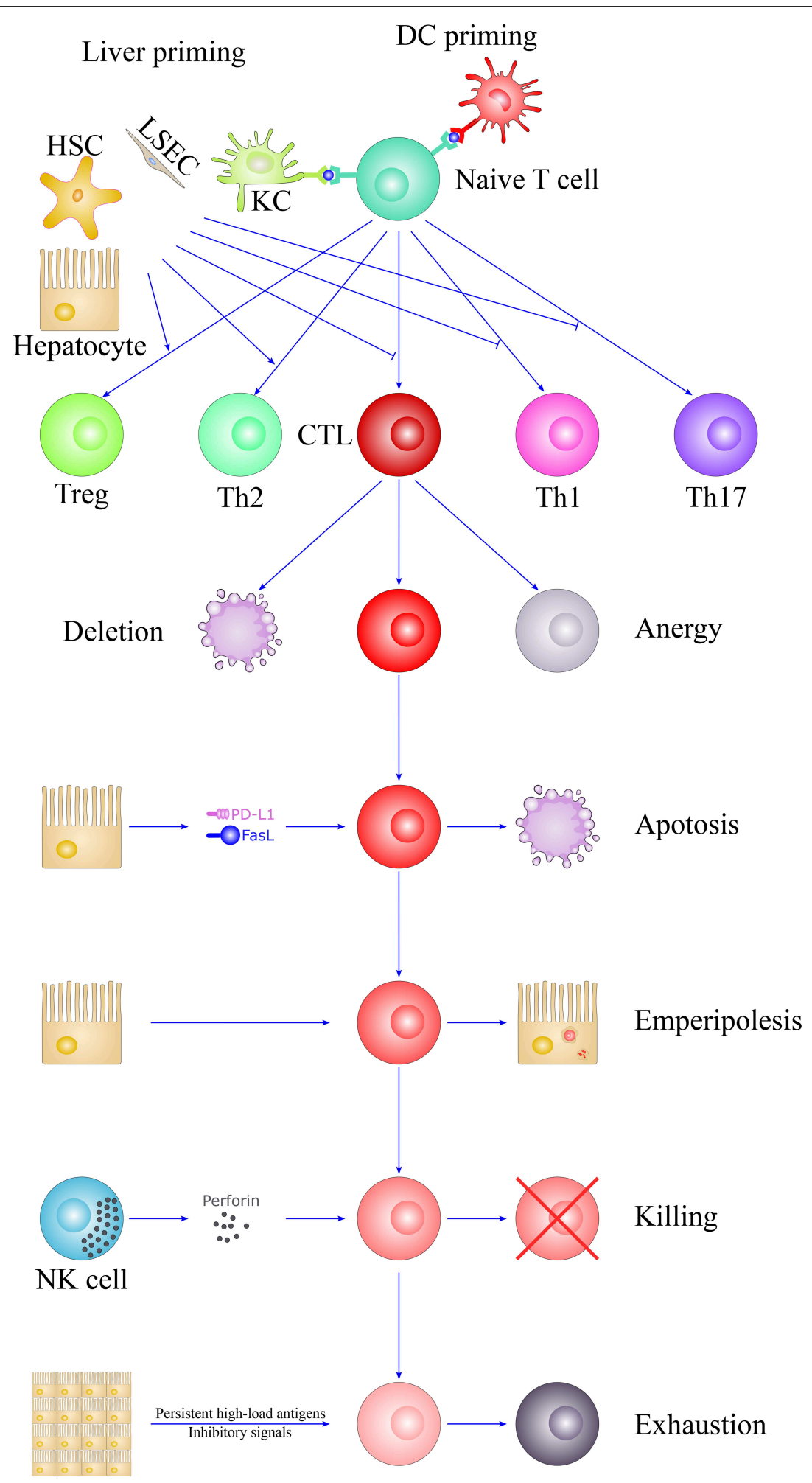

FIGURE 3 | The fate of T cells in liver tolerance. The unique liver microenvironment determines the fate of T cells after activation. T cells were primed by DCs in secondary lymphoid organs or diverse hepatic-resident immobile non-professional APCs in the liver, such as hepatocytes, LSECs, KCs, and HSCs. They are insufficient to optimally prime T cells, which lead to the removal of alloreactive CTLs and suppress the differentiation of proinflammatory Th1 and Th17 cells but favor the skewing of immunosuppressive Th2 and Tregs. The liver is also referred as the graveyard of T cells, suggesting the specific ability of the liver to destroys T cells. 
FIGURE 3 | Activated T cells would largely eliminate through clonal deletion, clonal anergy, apoptosis, "suicidal emperipolesis," NK cell killing and T cell exhaustion, thus leading to liver tolerance. HSC, hepatic stellate cell; LSEC, liver sinusoidal endothelial cell; DC, dendritic cell; NK, natural killer cell; CTL, cytotoxic T lymphocyte; KC, Kupffer cell; Th1, T helper cell 1; Th2, T helper cell 2; Th17, T helper cell 17; Treg, Regulatory T cell; PD-L1, programmed death ligand 1; FasL, Fas ligand; APC, Antigen-presenting cell.

(41). Furthermore, LSECs are able to induce $\mathrm{CD} 4^{+} \mathrm{T}$ cells apoptosis via the Fas/FasL pathway (42). LSECs-mediated CD8 ${ }^{+}$ $\mathrm{T}$ cell tolerance is antigen-dose-dependent, meaning that lowdose cross-presenting antigens induces immune tolerance, while high-dose induces effector T cells (43). CD8 ${ }^{+} \mathrm{T}$ cells activated by LSECs may exhibit a distinctive phenotype of CD25 ${ }^{\text {low }} \mathrm{CD} 44^{\text {high }}$ CD62 $\mathrm{L}^{\text {high}}$, which fails to show specific cytotoxicity in vivo (44). The interaction of LSECs with naïve $\mathrm{CD}^{+} \mathrm{T}$ cells would in turn promote the tolerogenic maturation of LSECs, characterized by increased expression of MHC class I and programmed death ligand 1 (PD-L1). LSECs can also induced $\mathrm{CD} 8^{+} \mathrm{T}$ cells apoptosis in a PD-L1 -dependent manner (44). Besides, researchers found that LSEC C-type lectin secreted by LSECs negatively regulates the immune response by specifically recognizing activated $\mathrm{T}$ cells via $\operatorname{CD} 44(45,46)$.

\section{Role of KCs}

KCs are liver-resident macrophages and account for onethird of the non-parenchymal cells in the liver and almost $90 \%$ of all residential macrophages in the body (47). Under physiological conditions, KCs are maintained by self-renewal from local precursors, whereas in response to inflammation, $\mathrm{KCs}$ are differentiated from infiltrated bone marrow-derived monocytes. KCs predominantly reside in the periportal region of the sinusoidal lumen, where they are optimally located to respond to systemic or gut-derived antigens and circulating immune cell populations. KCs are equipped with an array of scavenger receptors, Toll-like receptors, complement receptors and Fc receptors through which they detect, bind and internalize pathogens, accompanied by the production of cytokines and chemokines, such as tumor necrosis factor- $\alpha$ (TNF- $\alpha$ ), IL-1 $\beta$, IL6, IL-12, and IL-18 $(37,48,49)$. Under steady-state conditions, KCs also serve as tolerogenic APCs by expressing low levels of MHC class II molecules and costimulatory molecules and secrete anti-inflammatory mediators, such as IL-10, transforming growth factor (TGF)- $\beta 1$, nitric oxide, or prostaglandin E2, which can suppress antigen-specific $\mathrm{T}$ cells activation (50-53). KCs also strongly express the coinhibitory molecules programmed death (PD-1) and PD-L1, which can also inhibit the proliferation and functions of $\mathrm{T}$ cells by directly contacting them $(54,55)$. Furthermore, the interplay between KCs and hepatic Tregs is critical for IL-10 production and the induction of systemic $\mathrm{T}$ cell tolerance to hepatocyte-derived antigens (56). The role of KCs in organ transplantation induction has long been implicated in animal transplantation model (57-59). Early studies reported that KCs could contribute to absorption and subsequent clearance of alloreactive antibodies $(60,61)$. More recently, Chen et al. demonstrated that the deletion of graft KCs using gadolinium trichloride prevented the apoptosis of recipient $\mathrm{T}$ cells and consequently spontaneous graft acceptance in a rat liver transplantation model. The apoptosis of $\mathrm{T}$ cells induced by KCs was related to nuclear factor kappa B (NF-кB) activity and the Fas/FasL pathway, which was associated with spontaneous liver tolerance (62). However, when this approach was examined in a mouse liver transplantation model, the deletion of graft KCs using clodronate liposomes retained liver allograft acceptance (63). It is also worth to note that in the setting of transplantation, a large proportion of donor-derived KCs are being substituted by recipient-derived macrophages over time after transplantation. The recipient-derived macrophages are thought to be more immunogenic and thus able to promote graft pathology $(55,64,65)$.

\section{Role of Liver DCs}

DCs are professional APCs that play critical roles in the instigation and regulation of immune responses $(66,67)$. The general ontogeny, function and classification have been well-described elsewhere $(68,69)$. The liver harbors more interstitial DCs than any other non-lymphoid organs, including classical myeloid DCs (mDCs) and plasmacytoid DCs (pDCs) (70). They predominantly reside around the portal triad and central vein, with a few cells scattered interstitially between hepatocytes. Due to continuous in situ exposure to gut-derived factors, freshly isolated murine hepatic DCs are resistant to lipopolysaccharide (LPS)-mediated maturation, which is termed the endotoxin tolerance phenomenon and is also observed in macrophages/monocytes $(71,72)$. Compared with secondary lymphoid tissue DCs, freshly isolated hepatic DCs are immature and less immunogenic, express low levels of MHC class II and costimulatory molecules (CD80 and CD86) and secrete low levels of IL-12 (73-76). They prefer to produce IL-10 and IL27 in response to LPS (77) and are less effective in priming naive allogeneic $\mathrm{T}$ cells and Th1 skewing while favoring Th2 cell polarization $(71,73,78,79)$. Human hepatic DCs favor the generation of Th2 cells and Tregs through an IL-10-dependent mechanism $(80,81)$. The liver is particularly enriched in pDCs, which can suppress effector T cells through IL-27/Stat3 pathwaydependent PD-L1 expression and induce IL-10-producing Tregs via inducible costimulatory ligand (ICOS-L) expression $(82,83)$.

DCs were thought to be key mediators in spontaneous hepatic allograft tolerance due to their central roles in regulating the immune response. The trigger of allograft immunity relies on three antigen recognition pathways: the direct pathway, indirect pathway, and semi-direct pathway $(84,85)$. Donor hepatic DCs quickly migrate to the recipient graft-draining lymphoid tissues as passenger leukocytes, where they directly present intact, donor (allogeneic) MHC molecules to alloreactive $\mathrm{T}$ cells. The direct allorecognition pathway is considered the dominant pathway of acute rejection. Although this phenomenon exists in almost all types of organ transplantation, the phenotype and function of 
donor DCs determines the fate of alloreactive $\mathrm{T}$ cells, resulting in either graft tolerance or graft rejection. The tolerogenic properties of hepatic DCs may tilt the balance toward graft tolerance. Liver allografts were acutely rejected when donor hepatic DCs were depleted using a CD11c-DTR mouse model before transplantation (86). However, when the interstitial DC quantity was significantly increased by FMS-like tyrosine kinase 3 ligand (Flt3L) treatment of the donor, liver allografts were also rejected acutely $(87,88)$. Acute rejection is associated with a marked IL-12 reduction by donor DCs. IL-12 neutralization enhanced the apoptotic death of T cells within both the grafts and the spleen and prolonged the survival of grafts from Flt3L-treated donors. Donor grafts from DAP $12^{-/-}$mice, whose $\mathrm{mDCs}$ exhibit a more mature phenotype than that of naïve mice with enhanced migratory and $\mathrm{T}$ cell allostimulatory abilities, failed to induce tolerance and were rejected acutely (89).

Following transplantation, donor-derived hepatic DCs were quickly diminished and replaced by recipient DCs, which peaked on post-operative day 7 and persisted indefinitely. These recipient DCs acquired and expressed intact donor MHC molecules via cell-cell contact or extracellular vesicles and were thus termed cross-dressed DCs (90-94). Interestingly, around $60 \%$ of host DCs in liver grafts are cross-dressed DCs. They express high levels of PD-L1 and IL-10, subvert the host anti-donor $\mathrm{T}$ cell responses and promote liver transplantation tolerance (95). In contrast, the non-cross-dressed DCs show a minimal suppressor function.

Although the role of DCs in spontaneous hepatic allograft tolerance remains to be further investigated, the manipulation of DCs, such as by in situ targeting or infusion after ex vivo generation, has been shown to be a promising approach for promoting donor-specific tolerance. The ex vivo generation of regulatory DCs can be achieved by culturing DC progenitors using low concentrations of granulocyte-macrophage colonystimulating factor (GM-CSF) \pm IL-4, with the addition of one or more pharmacological agents, such as IL-10, dexamethasone, Vitamin D3, or rapamycin (96-98). The in situ manipulation of DCs, such as by the delivery of immunomodulatory factors targeting DCs to regulate alloreactive $\mathrm{T}$ cell responses, is an alternative approach to achieve donor-specific transplantation tolerance (99). In experimental transplantation models, the manipulation of DCs showed encouraging efficacy and safety in organ-specific tolerance induction (99-101). Several earlyphase clinical trials of ex vivo-generated DCs in living-donor liver transplantation have recently been initiated (clinicaltrials.gov identifier: NCT03164265 and NCT04208919) $(99,102)$.

\section{Role of HSCs}

HSCs account for about 5-8\% of liver non-parenchymal cells (103). HSCs are distributed in the space of Disse, in which the cytoplasm is rich in retinoid lipid droplets and vitamin A and regulate the blood flow in the sinusoids of the liver. HSCs undergo activation in response to liver injury and inflammatory events $(104,105)$. Activated HSCs secrete cytokines, chemokines and extracellular matrix to participate in the pathogenesis of liver fibrogenesis.
The HSCs are potent liver-resident APCs that have the ability of tolerizing $\mathrm{T}$ cells. They can induce $\mathrm{T}$ cells apoptosis through the PD-L1, B7-H4, and the Fas/FasL signaling pathways and veto the activation of $\mathrm{CD}^{+} \mathrm{T}$ cells through a CD54dependent pathway, thereby suppressing the $\mathrm{T}$ cell immune response and maintaining homeostasis and tolerance in the liver (106-111). In a mouse islet transplantation model, cotransplantation of HSCs and islet cells reduced the rejection rate and prolonged the survival of the graft through TRAIL-mediated $\mathrm{T}$ cell apoptosis and reduced immune cell infiltration in the graft $(112,113)$. Activated HSCs induce the conversion of mature monocytes into myeloid-derived suppressor cells (MDSCs), which may contribute to liver immunosuppression $(114,115)$. In addition, HSCs also participate in immune tolerance by secreting the immunosuppressive factors TGF- $\beta 1$ and all-trans retinoic acid, thereby promoting the differentiation and proliferation of Foxp3 ${ }^{+}$Tregs (116-119). In liver transplantation models, activated HSCs induced immune tolerance by inducing $\mathrm{T}$ cell apoptosis and stimulating IL-10 and TGF- $\beta 1$ production (110). Activated HSCs also promote transplantation tolerance by inducing selective expansion of allogeneic Tregs and reducing inflammation and alloimmunity (117).

\section{Role of NK and NKT Cells}

NK cells and NKT cells are innate lymphocytes particularly enriched in the liver. Following transplantation, NK cells and NKT cells persist in the liver and blood, unlike donor $\mathrm{T}$ cells, B cells, and DCs, which migrate into secondary lymphoid organs and are rejected rapidly. This phenomenon suggests that these cells are resistant to rejection and may contribute to liver tolerance (120). NK cells represent $\sim 30-50 \%$ of total lymphocytes in the liver, with constitutive cytolytic functions that are responsible for exogenous pathogen clearance and tumor immunity (121-123). The function of NK cells is controlled by the balance of a series of activatory and inhibitory signals receptors constitutively expressed on the cell surface. NK cells can readily recognize allogeneic cells via a unique self-non-self recognition system, termed "missing self" or "missing ligand" recognition, as MHC-incompatible allogeneic cells lack self MHC class I molecules to engage NK inhibitory receptors $(124,125)$. However, the exact role of NK cells remains unclear. There is evidence that NK cells contribute to both allograft rejection and tolerance in liver transplantation.

Donor-derived NK cells play a major role in liver tolerance, while recipient-derived NK cells are inclined to reject allografts (126). Following transplantation, donor-derived NK cells migrate from liver grafts into the recipient circulation and sustained for $\sim 2$ weeks (127). While some of them may persist within the liver graft for decades (128). Donor hepatic NK cells promote tolerance, possibly by directly killing recipient immune cells including activated $\mathrm{T}$ cells, as suggested by an in vitro study in which alloantigen-activated $\mathrm{T}$ cells express stressinduced NKG2D ligands via the ATM/ATR pathway and became susceptible to autologous NK cell lysis (129). Alternatively, hepatic NK cells may kill recipient immature dendritic cells recruited to the allograft, as suggested by the fact that NK cells lyse immature DCs at sites of inflammation (130). However, there 
is no clear in vivo evidence of the above hypothesis (Figure 2). Infusion of donor liver NK cells could attenuate liver allograft acute rejection and prolong graft survival in rats (131). Although recipient NK cells can mediate rejection by directly lysing allogeneic liver cells, they become phenotypically distinct and functionally less responsive after migrating to the liver, due to the hepatic microenvironment (132). Recently, Jamil et al. reported that recipient $\mathrm{NK}$ cells switched to a tolerant phenotype, as reflected by reduced activating receptor expression, cytotoxicity and cytokine production (133). The tolerance of recipient NK cells occurs upstream of the MHC class I-mediated education via perturbation of the IL-12/STAT4 signaling pathway. Outside of the liver, recipient NK cells kill donor passenger DCs, thereby limiting the activation of $\mathrm{T}$ cells by the direct pathway, but favoring the indirect pathway-primed alloreactive $\mathrm{T}$ cell response, which contributes to tolerance induction (134-137). In addition, clinical data also showed the correlation of NK cells with allograft tolerance in liver transplantation, but information regarding the origin of the NK cells (from the recipient or donor) was lacking $(130,138,139)$.

NKT cells are liver-resident lymphocytes that actively patrol the liver. They share features of both NK and T cells and recognize the lipid antigens from either the host or a microbe presented by the non-classical MHC class I-like molecule CD1. NKT cells contribute to most of the immune responses in the liver and play diverse roles in acute liver injury, liver fibrosis and tolerance. NKT cells are believed to promote liver tolerance induction (140). NKT (J $\alpha 281)$ knockout in the donor liver graft was associated with extensive lymphocytic infiltration of portal triads and bile duct epithelium and significantly impaired the graft survival in mouse liver transplantation models (141).

\section{THE ADAPTIVE IMMUNE TOLERANCE MECHANISMS}

\section{The Fate of T Cells}

$\mathrm{T}$ cells are the major executor of transplantation rejection, doing so by directly destroying allograft cells. The fate of $\mathrm{T}$ cells after their activation determines the outcome of transplantation: either allograft tolerance or rejection. Naïve $\mathrm{T}$ cells usually lack permission to enter the parenchyma of most organs, due to the lack of the adhesion molecules and chemokine receptors required for adhesion to endothelial cells or subsequent transendothelial migration (142). Naïve $\mathrm{T}$ cells circulate in the blood and migrate into secondary lymphoid organs, where they are activated by interacting with DCs. The $\mathrm{T}$ cell activation results in adhesion molecule and chemokine receptor upregulation, which allows them to migrate and infiltrate tissues. In the liver, however, the situation is different. The unique liver microenvironment, with its slow blood flow and fenestrated endothelium in the narrow hepatic sinusoids, permits the continuous functional interaction between circulating naive $\mathrm{T}$ cells and the diverse hepatic-resident immobile non-professional APCs, as mentioned above. This makes the liver the only non-lymphoid organ that can prime naïve $\mathrm{T}$ cells locally independently of DCs and secondary lymphoid organs (143). These non-professional APCs are generally tolerogenic, as reflected in their low expression of MHC molecules, costimulatory molecules and proinflammatory cytokines but rather high expression of coinhibitory molecules and anti-inflammatory cytokines (43, 44, 51, 52, 108, 144-148). They are insufficient to optimally prime the $\mathrm{T}$ cells, which leads to the removal of alloreactive $\mathrm{T}$ cells, thus promoting tolerance $(49,149-151)$.

A classic theory refers to the liver as the graveyard of $\mathrm{T}$ cells, suggesting the specific ability of the liver to retain and eliminate activated T cells $(152,153)$. The liver destroys T cells undergoing apoptosis or activated $\mathrm{T}$ cells recognizing their antigen in situ by clonal deletion, clonal anergy and $\mathrm{T}$ cell exhaustion. Activated $\mathrm{CD}^{+} \mathrm{T}$ cells perfused through the liver are selectively retained primarily by ICAM-1-expressing hepatocytes, LESCs and KCs and subsequently undergo apoptosis (154). Another important mechanism involved in liver tolerance is the phenomenon that liver-activated T cells may be rapidly destroyed by endosomal/lysosomal-depended degradation following an active invasion of hepatocytes expressing the recognition of their cognate antigens (155). This unique mechanism of peripheral deletion was termed "suicidal emperipolesis" and results in the deletion of at least $75 \%$ of antigen-specific $\mathrm{CD}^{+} \mathrm{T}$ cells within the first $24 \mathrm{~h}$ following activation in the liver.

Other hepatic non-professional APCs, such as LESCs, KCs, and HSCs, also play an important role in liver tolerance through clonal anergy or the deletion of $\mathrm{T}$ cells within the hepatic microenvironment. In mouse liver transplantation models, activated $\mathrm{CD}^{+} \mathrm{T}$ cells infiltrating the liver allograft were eliminated by locally induced apoptotic cell death (156). Thus, the systemic administration of mouse IL-2, which rescued $\mathrm{CD}^{+} \mathrm{T}$ cells from apoptosis, induces acute graft rejection $(156,157)$. In human liver allografts, prominent $\mathrm{T}$ cell apoptosis in the sinusoids was also evident in biopsy specimens (158). Even if some activated $\mathrm{CD}^{+} \mathrm{T}$ cells survive these early depletion processes, they may progress to a functionally defective state, known as exhaustion. $\mathrm{T}$ cell exhaustion is another pattern of $\mathrm{T}$ cell dysfunction that has been frequently studied in the era of chronic viral infection and antitumor immunity (159). T cells become exhausted when encountering a persistent high load of antigens or receiving inhibitory signals, and this condition is characterized by a progressive loss of effector functions and proliferative capacity (160-164). This would most likely happen in the setting of liver transplantation, where the allograft is a large-sized mass and the immunosuppressive microenvironment has an abundant amount of inhibitory signals. Direct evidence of alloreactive $\mathrm{CD}^{+} \mathrm{T}$ cell exhaustion was observed following the rapid and extensive activation of $\mathrm{T}$ cells early after transplantation in mice (165). However, the contribution of $\mathrm{T}$ cell exhaustion to spontaneous liver tolerance needs to be further explored.

$\mathrm{CD}^{+}{ }^{+} \mathrm{T}$ cells help coordinate immune responses primarily by secreting cytokines that target other immune cells to orchestrate a synchronized immune response (166). After activation, naive 
$\mathrm{CD}^{+}{ }^{+} \mathrm{T}$ cells differentiate into distinct $\mathrm{T}$ helper cell lineages, including IFN- $\gamma$-producing Th1 cells, IL-4-producing Th2 cells, IL-17-producing Th17 cells, and Tregs (167). The cytokine environment dictates the differentiation and conversion of $\mathrm{CD} 4^{+}$ $\mathrm{T}$ cells. The profile of the hepatic microenvironment suppresses the differentiation of proinflammatory Th1 and Th17 cells but favors the skewing of immunosuppressive Th2 and Tregs, which promote allograft tolerance. Tregs are the most wellknown suppressor $\mathrm{T}$ cells and play an important role in both transplantation tolerance induction and maintenance (168-170). The frequency of Tregs was shown to be increased in liver grafts and host spleens after transplantation (171). The depletion of host Tregs enhanced the $\mathrm{T}$ cell response and reduced apoptosis, thereby abrogating spontaneous liver allograft acceptance in a mouse model $(171,172)$.

\section{OTHER PROPOSED LIVER TOLERANCE MECHANISMS}

\section{Role of Soluble Donor MHC-I Molecules}

Liver allografts release massive amounts of soluble MHC class I molecules that persist in the recipient circulation at high concentrations (173), which may act as a plausible mechanism of liver transplantation tolerance. The activation of $\mathrm{T}$ cells requires the first signal to be provided by the $\mathrm{MHC} /$ antigenpeptide complex and the second signal to be provided by the costimulatory signal. Stimulation of T cell receptors in the absence of a co-stimulatory signal induces T cells apoptosis (174). Due to the lack of costimulatory molecules, the binding of soluble MHC molecules to $\mathrm{T}$ cells leads to tolerance of antigen-specific $\mathrm{T}$ cells and is widely used in the study of allogeneic transplantation. A large number of soluble MHC class I molecules are released into the circulatory system in liver transplantation and are involved in inducing immune tolerance and promoting the graft survival (173, 175-178).

Although earlier studies reported that MHC class I-deficient liver allografts were still accepted indefinitely (179), the low immunogenicity due to MHC-deficient makes these studies difficult to interpret. Other studies have shown that soluble MHC molecules inhibit transplant rejection and prolong the graft survival by inhibiting allergic $\mathrm{T}$ cells and inducing CTL apoptosis in a dose-dependent manner (180-185). The advent of MHC/antigen-peptide multimer technology has provided Tcell receptor (TCR) with a relatively high-affinity ligand and an effective way of regulating the activation and function of $\mathrm{T}$ cells. Soluble MHC class I molecules can also neutralize antibodies by binding to alloantibodies, thereby preventing alloantibodymediated rejection (175). Furthermore, researchers constructed a mouse soluble MHC dimer and found that it was able to bind to TCR specifically and regulate the TCR expression and phosphorylation, thereby inhibiting the activation and cytotoxicity of T cells $(186,187)$. Fried et al. reported in 2005 that rat RT1.A-Fc dimers were able to prolong the survival time of heart grafts, suggesting the utility of soluble MHC dimers for inhibiting transplant rejection. pMHC dimer may therefore be useful for inhibiting transplant rejection (188).

\section{Role of Passenger Leukocytes and Microchimerism}

Passenger leukocytes are donor leukocytes that circulate in the recipient's lymphatic tissue after transplantation (189, 190). Microchimerism refers to the persistently low levels of donor cells ( $<1$ per $10^{4}$ or $10^{5}$ cells) within the peripheral circulation of the transplant recipient (191). The role of passenger leukocytes and microchimerism in organ transplantation has been controversial. Studies have found that passenger leukocytes are important factors for promoting graft rejection in skin, lung and kidney transplants (192-194). However, in liver transplantation, passenger leukocytes and microchimerism can induce transplant immune tolerance.

Liver passenger leukocytes include B cells, T cells, NK cells, NKT cells, and DCs, which quickly enter the recipient's peripheral circulation and then enter the secondary lymphoid organs after transplantation (120). Previous studies detected a large number of donor passenger leukocytes in recipient secondary lymphoid organs or peripheral blood after liver transplantation in rat, mouse and human models $(4,189,195)$. Starzl et al. proposed that liver allografts induced tolerance by the lymphocyte balance between the host and the passenger leukocytes (i.e., the ability to reach a stable chimeric state) (191). Subsequent studies have shown that passenger leukocytes interact with allogeneic $\mathrm{CD}^{+} \mathrm{T}$ cells in secondary lymphoid organs, which is an early event in spontaneous liver tolerance $(120,196)$. Removal of passenger leukocytes by irradiating the donor graft before transplantation results in acute rejection of the graft (196, 197). However, tolerance can be restored by supplementation of liver passenger leukocytes or spleen lymphocytes (196-198). Further research found elevated IL- 2 and IFN- $\gamma$ mRNA levels and apoptotic T cells in transplant-tolerant recipients' secondary lymphoid organs $(195,199)$. However, other researchers have also suggested that microchimerism is not a major factor in spontaneous liver tolerance, as it fails to predict patients who are suitable for the discontinuation of immunosuppressive therapy $(200,201)$. Therefore, microchimerism may be the result of tolerance rather than the cause (202). In summary, more research is needed on the role of passenger leukocytes and microchimerism in immune tolerance in liver transplantation.

\section{Role of the High-Load Antigen Effect}

The liver is the largest internal solid organ in the body, which may favor allograft tolerance due to its large tissue mass and high-load alloantigens (MHC molecules). The high-load alloantigens dilutes the finite $\mathrm{T}$ cell clones and cytokine levels, leading to a low density of alloreactive $\mathrm{T}$ cells and insufficient cytokines, and thus potentially result in exhaustion of $\mathrm{T}$ cells and subsequent tolerance. This hypothesis was supported by the results of animal transplantation experiments, which showed that larger skin grafts extended the survival $(203,204)$, as did multiple organ transplantation (205). In contrast, small grafts have higher rejection rates in rat liver transplant models (206208). In the reduced-volume liver transplantation model, the recipient's tolerance to the graft increased as did the antigen load, which is consistent with other findings (209). In clinical studies, 
combined liver-kidney transplantation has been associated with a weaker immune response, lower rejection rate and higher survival rate $(9,10,210)$. These findings suggested that a high antigen load may partially account for liver tolerance, although the mechanism remains unclear. Some researchers have proposed plausible explanations for liver tolerance: first, the liver's large size dilutes alloreactive T cells and cytokines, which lower the alloimmune responses $(211,212)$; second, the liver allograft harbors a large number of passenger leukocytes that may contribute to tolerance as discussed above; last, the high-load antigens favor $\mathrm{T}$ cell exhaustion (213).

\section{CONCLUDING REMARKS}

The unique tolerogenic hepatic microenvironment is due to the hepatic acinus anatomy and the complex cellular network, thus enabling the local activation of naïve $\mathrm{T}$ cells by interacting with diverse hepatic-resident immobile non-professional APCs and resulting in the dysfunction and depletion of $\mathrm{T}$ alloreactive $\mathrm{T}$ cells. Outside the liver graft, passenger hepatic DCs and recipient NK cells also limit the priming of alloreactive $\mathrm{T}$ cells. In addition, soluble donor MHC I molecules, the passenger leukocyte theory and the high-load antigen effect may also be important for achieving liver tolerance. These tolerogenic

\section{REFERENCES}

1. Watt KDS, Pedersen RA, Kremers WK, Heimbach JK, Charlton MR. Evolution of causes and risk factors for mortality post-liver transplant: results of the NIDDK long-term follow-up study. Am J Transplant. (2010) 10:1420-7. doi: 10.1111/j.1600-6143.2010.03126.x

2. Feng S, Bucuvalas J. Tolerance after liver transplantation: where are we? Liver Transpl. (2017) 23:1601-14. doi: 10.1002/lt. 24845

3. Zimmermann FA, Davies HS, Knoll PP, Gokel JM, Schmidt T. Orthotopic liver allografts in the rat. The influence of strain combination on the fate of the graft. Transplantation. (1984) 37:406-10. doi: 10.1097/00007890-198404000-00019

4. Qian S, Demetris AJ, Murase N, Rao AS, Fung JJ, Starzl TE. Murine liver allograft transplantation: tolerance and donor cell chimerism. Hepatology. (1994) 19:916-24. doi: 10.1002/hep.1840190418

5. Calne RY, Sells RA, Pena JR, Davis DR, Millard PR, Herbertson BM, et al. L. Induction of immunological tolerance by porcine liver allografts. Nature. (1969) 223:472-6. doi: 10.1038/223472a0

6. Benítez C, Londoño MC, Miquel R, Manzia TM, Abraldes JG, Lozano JJ, et al. Prospective multicenter clinical trial of immunosuppressive drug withdrawal in stable adult liver transplant recipients. Hepatology. (2013) 58:1824-35. doi: 10.1002/hep.26426

7. Feng S, Ekong UD, Lobritto SJ, Demetris AJ, Roberts JP, Rosenthal P, et al. Complete immunosuppression withdrawal and subsequent allograft function among pediatric recipients of parental living donor liver transplants. JAMA. (2012) 307:283-93. doi: 10.1001/jama.2011.2014

8. Opelz G, Margreiter R, Döhler B. Prolongation of long-term kidney graft survival by a simultaneous liver transplant: the liver does it, and the heart does it too. Transplantation. (2002) 74:1390-4. doi: 10.1097/00007890-200211270-00008

9. Rasmussen A, Davies HF, Jamieson NV, Evans DB, Calne RY. Combined transplantation of liver and kidney from the same donor protects the kidney from rejection and improves kidney graft survival. Transplantation. (1995) 59:919-21. doi: 10.1097/00007890-199503000-00025 mechanisms determine the fate of $\mathrm{T}$ cells toward clonal deletion, clonal anergy and exhaustion, which eventually leads to tolerance (Figure 3). However, other critical mechanisms may exist, so further studies are yet needed. Understanding the mechanisms underlying the unique immunologically privileged liver organ is valuable for transplantation management and autoimmune disease treatment.

\section{AUTHOR CONTRIBUTIONS}

All authors listed have made a substantial, direct and intellectual contribution to the work, and approved it for publication.

\section{FUNDING}

This work was supported in part by research grants from the National Key Research and Development Program of China (2018YFA0108700), NSFC Projects of International Cooperation and Exchanges (81720108004), National Natural Science Foundation of China (81570279), National Center for Child Health and Development (30-20), and the Ministry of Education, Culture, Sports, Science and Technology of Japan (17H04277, 18F17794, 19K18045).
10. Creput C, Durrbach A, Samuel D, Eschwege P, Amor M, Kriaa F, et al. Incidence of renal and liver rejection and patient survival rate following combined liver and kidney transplantation. Am J Transplant. (2003) 3:34856. doi: 10.1034/j.1600-6143.2003.00050.x

11. Sawada T, Asanuma Y, Furuya T, Shibata S, Yasui O, Sato T, et al. Induction of systemic tolerance in islet allograft by liver transplantation. Transplant Proc. (2001) 33:2995-9. doi: 10.1016/S0041-1345(01)02285-0

12. Qian S, Fung JJ, Sun H, Demetris AJ, Starzl TE. Transplantation unresponsiveness induced by liver allografts in mouse strains with various histocompatibility disparities. Transplant Proc. (1992) 24:1605-6.

13. Lautt WW, Greenway CV. Conceptual review of the hepatic vascular bed. Hepatology. (1987) 7:952-63. doi: 10.1002/hep.1840070527

14. Rappaport AM. The microcirculatory hepatic unit. Microvasc Res. (1973) 6:212-28. doi: 10.1016/0026-2862(73)90021-6

15. Seki E, Brenner DA. Toll-like receptors and adaptor molecules in liver disease: update. Hepatology. (2008) 48:322-35. doi: 10.1002/hep.22306

16. Racanelli V, Rehermann B. The liver as an immunological organ. Hepatology. (2006) 43:S54-62. doi: 10.1002/hep.21060

17. Liu S, Gallo DJ, Green AM, Williams DL, Gong X, Shapiro RA, et al. Role of toll-like receptors in changes in gene expression and NF-kappa B activation in mouse hepatocytes stimulated with lipopolysaccharide. Infect Immun. (2002) 70:3433-42. doi: 10.1128/IAI.70.7.3433-3442.2002

18. Kubes P, Jenne C. Immune Responses in the Liver. Ann Rev Immunol. (2018) 36:247-77. doi: 10.1146/annurev-immunol-051116-052415

19. Warren A, Le Couteur DG, Fraser R, Bowen DG, McCaughan GW, Bertolino P. T lymphocytes interact with hepatocytes through fenestrations in murine liver sinusoidal endothelial cells. Hepatology. (2006) 44:118290. doi: 10.1002/hep. 21378

20. Bertolino P, Trescol-Biémont MC, Rabourdin-Combe C. Hepatocytes induce functional activation of naive $\mathrm{CD}^{+} \mathrm{T}$ lymphocytes but fail to promote survival. Eur J Immunol. (1998) 28:221-36. doi: 10.1002/(SICI)15214141(199801)28:01<221::AID-IMMU221>3.0.CO;2-F

21. Holz LE, Warren A, Le Couteur DG, Bowen DG, Bertolino P. CD8 ${ }^{+} \mathrm{T}$ cell tolerance following antigen recognition on hepatocytes. J Autoimmun. (2010) 34:15-22. doi: 10.1016/j.jaut.2009.08.005 
22. Dolina JS, Cechova S, Rudy CK, Sung SSJ, Tang WW, Lee J, et al. CrossPresentation of soluble and cell-associated antigen by murine hepatocytes is enhanced by collectrin expression. J Immunol. (2017) 198:234151. doi: 10.4049/jimmunol.1502234

23. Holz LE, Benseler V, Bowen DG, Bouillet P, Strasser A, O'Reilly L, et al. Intrahepatic murine CD8 T-cell activation associates with a distinct phenotype leading to Bim-dependent death. Gastroenterology. (2008) 135:989-97. doi: 10.1053/j.gastro.2008.05.078

24. Crispe IN. Hepatic T cells and liver tolerance. Nat Rev Immunol. (2003) 3:51-62. doi: 10.1038/nri981

25. Wahl C, Bochtler P, Schirmbeck R, Reimann J. Type I IFNproducing CD4 Valpha14i NKT cells facilitate priming of IL10-producing CD8 T cells by hepatocytes. J Immunol. (2007) 178:2083-93. doi: 10.4049/jimmunol.178.4.2083

26. Herkel J, Jagemann B, Wiegard C, Lazaro JFG, Lueth S, Kanzler S, et al. MHC class II-expressing hepatocytes function as antigen-presenting cells and activate specific CD4 T lymphocyutes. Hepatology. (2003) 37:107985. doi: 10.1053/jhep.2003.50191

27. DeTemple DE, Oldhafer F, Falk CS, Chen-Wacker C, Figueiredo C, Kleine $\mathrm{M}$, et al. Hepatocyte-induced $\mathrm{CD}^{+}{ }^{+} \mathrm{T}$ cell alloresponse is associated with major histocompatibility complex class II up-regulation on hepatocytes and suppressible by regulatory T cells. Liver Transpl. (2018) 24:40719. doi: 10.1002/lt.25019

28. Wiegard C, Wolint P, Frenzel C, Cheruti U, Schmitt E, Oxenius A, et al. Defective $\mathrm{T}$ helper response of hepatocyte-stimulated CD4 T cells impairs antiviral CD8 response and viral clearance. Gastroenterology. (2007) 133:2010-8. doi: 10.1053/j.gastro.2007.09.007

29. Burghardt S, Claass B, Erhardt A, Karimi K, Tiegs G. Hepatocytes induce Foxp $3^{+}$regulatory $\mathrm{T}$ cells by notch signaling. J Leukocyte Biol. (2014) 96:571-7. doi: 10.1189/jlb.2AB0613-342RR

30. Holman NS, Church RJ, Nautiyal M, Rose KA, Thacker SE, Otieno MA, et al. Hepatocyte-derived exosomes promote liver immune tolerance: possible implications for idiosyncratic drug-induced liver injury. Toxicol Sci. (2019) 170:499-508. doi: 10.1093/toxsci/kfz112

31. Sierro F, Tay SS, Warren A, Le Couteur DG, McCaughan GW, Bowen DG, et al. Suicidal emperipolesis: a process leading to cell-in-cell structures, $T$ cell clearance and immune homeostasis. Curr Mol Med. (2015) 15:81927. doi: 10.2174/1566524015666151026102143

32. Sørensen KK, Simon-Santamaria J, McCuskey RS, Smedsrød B. Liver sinusoidal endothelial cells. Comp Physiol. (2015) 5:1751-74. doi: 10.1002/cphy.c140078

33. Carambia A, Frenzel C, Bruns OT, Schwinge D, Reimer R, Hohenberg $\mathrm{H}$, et al. Inhibition of inflammatory $\mathrm{CD} 4 \mathrm{~T}$ cell activity by murine liver sinusoidal endothelial cells. J Hepatol. (2013) 58:112-8. doi: 10.1016/j.jhep.2012.09.008

34. Limmer A, Ohl J, Wingender G, Berg M, Jüngerkes F, Schumak B, et al. Cross-presentation of oral antigens by liver sinusoidal endothelial cells leads to CD8 T cell tolerance. Eur J Immunol. (2005) 35:297081. doi: 10.1002/eji.200526034

35. Rubinstein D, Roska AK, Lipsky PE. Liver sinusoidal lining cells express class II major histocompatibility antigens but are poor stimulators of fresh allogeneic T lymphocytes. J Immunol. (1986) 137:1803-10.

36. Knolle PA, Gerken G. Local control of the immune response in the liver. Immunol Rev. (2000) 174:21-34. doi: 10.1034/j.1600-0528.2002.017408.x

37. Crispe IN. The liver as a lymphoid organ. Annu Rev Immunol. (2009) 27:147-63. doi: 10.1146/annurev.immunol.021908.132629

38. Knolle PA, Schmitt E, Jin S, Germann T, Duchmann R, Hegenbarth $\mathrm{S}$, et al. Induction of cytokine production in naive $\mathrm{CD} 4(+) \mathrm{T}$ cells by antigen-presenting murine liver sinusoidal endothelial cells but failure to induce differentiation toward Th1 cells. Gastroenterology. (1999) 116:142840. doi: 10.1016/S0016-5085(99)70508-1

39. Schölzel K, Schildberg FA, Welz M, Börner C, Geiger S, Kurts C, et al. Transfer of MHC-class-I molecules among liver sinusoidal cells facilitates hepatic immune surveillance. J Hepatol. (2014) 61:6008. doi: 10.1016/j.jhep.2014.04.028

40. Kruse N, Neumann K, Schrage A, Derkow K, Schott E, Erben U, et al. Priming of $\mathrm{CD}^{+} \mathrm{T}$ cells by liver sinusoidal endothelial cells induces
CD25low forkhead box protein 3-regulatory T cells suppressing autoimmune hepatitis. Hepatology. (2009) 50:1904-13. doi: 10.1002/hep.23191

41. Klugewitz K, Blumenthal-Barby F, Schrage A, Knolle PA, Hamann A, Crispe IN. Immunomodulatory effects of the liver: deletion of activated $\mathrm{CD}^{+}$effector cells and suppression of IFN-gamma-producing cells after intravenous protein immunization. J Immunol. (2002) 169:240713. doi: 10.4049/jimmunol.169.5.2407

42. Tokita D, Shishida M, Ohdan H, Onoe T, Hara H, Tanaka Y, et al. Liver sinusoidal endothelial cells that endocytose allogeneic cells suppress $\mathrm{T}$ cells with indirect allospecificity. J Immunol. (2006) 177:3615-24. doi: 10.4049/jimmunol.177.6.3615

43. Schurich A, Berg M, Stabenow D, Böttcher J, Kern M, Schild HJ, et al. Dynamic regulation of CD8 T cell tolerance induction by liver sinusoidal endothelial cells. J Immunol. (2010) 184:410714. doi: 10.4049/jimmunol.0902580

44. Diehl L, Schurich A, Grochtmann R, Hegenbarth S, Chen L, Knolle PA. Tolerogenic maturation of liver sinusoidal endothelial cells promotes B7homolog 1-dependent CD8 ${ }^{+}$T cell tolerance. Hepatology. (2007) 47:296305. doi: 10.1002/hep.21965

45. Yang Z, Li Q, Wang X, Jiang X, Zhao D, Lin X, et al. C-type lectin receptor LSECtin-mediated apoptotic cell clearance by macrophages directs intestinal repair in experimental colitis. Proc Natl Acad Sci USA. (2018) 115:110549. doi: 10.1073/pnas.1804094115

46. Tang L, Yang J, Liu W, Tang X, Chen J, Zhao D, et al. Liver sinusoidal endothelial cell lectin, LSECtin, negatively regulates hepatic T-cell immune response. Gastroenterology. (2009) 137:1498-508.e1-5. doi: 10.1053/j.gastro.2009.07.051

47. Bilzer M, Roggel F, Gerbes AL. Role of Kupffer cells in host defense and liver disease. Liver Int. (2006) 26:1175-86. doi: 10.1111/j.1478-3231.2006.01342.x

48. Jenne CN, Kubes P. Immune surveillance by the liver. Nat Immunol. (2013) 14:996-1006. doi: 10.1038/ni.2691

49. Thomson AW, Knolle PA. Antigen-presenting cell function in the tolerogenic liver environment. Nat Rev Immunol. (2010) 10:753-66. doi: 10.1038/nri2858

50. Bissell DM, Wang SS, Jarnagin WR, Roll FJ. Cell-specific expression of transforming growth factor-beta in rat liver. Evidence for autocrine regulation of hepatocyte proliferation. J Clin Invest. (1995) 96:44755. doi: 10.1172/JCI118055

51. Knolle PA, Uhrig A, Protzer U, Trippler M, Duchmann R, Meyer zum Büschenfelde $\mathrm{KH}$, et al. Interleukin-10 expression is autoregulated at the transcriptional level in human and murine Kupffer cells. Hepatology. (1998) 27:93-9. doi: 10.1002/hep.510270116

52. You Q, Cheng L, Kedl RM, Ju C. Mechanism of $\mathrm{T}$ cell tolerance induction by murine hepatic Kupffer cells. Hepatology. (2008) 48:97890. doi: 10.1002/hep. 22395

53. Roland CR, Walp L, Stack RM, Flye MW. Outcome of Kupffer cell antigen presentation to a cloned murine Th1 lymphocyte depends on the inducibility of nitric oxide synthase by IFN-gamma. J Immunol. (1994) 153:5453-64.

54. Li T, Zhu JY, Wang FS, Leng XS. Down-Regulation of donor Kupffer cell B7 expression reduced recipient lymphocyte activation and secretion of interleukin-2 in vitro. Transpl Proc. (2015) 47:2985-90. doi: 10.1016/j.transproceed.2015. 10.038

55. Heymann F, Peusquens J, Ludwig-Portugall I, Kohlhepp M, Ergen C, Niemietz $P$, et al. Liver inflammation abrogates immunological tolerance induced by Kupffer cells. Hepatology. (2015) 62:279-91. doi: 10.1002/hep.27793

56. Breous E, Somanathan S, Vandenberghe LH, Wilson JM. Hepatic regulatory $\mathrm{T}$ cells and Kupffer cells are crucial mediators of systemic $\mathrm{T}$ cell tolerance to antigens targeting murine liver. Hepatology. (2009) 50:61221. doi: 10.1002/hep. 23043

57. Kamei T, Callery MP, Flye MW. Kupffer cell blockade prevents induction of portal venous tolerance in rat cardiac allograft transplantation. J Surg Res. (1990) 48:393-6. doi: 10.1016/0022-4804(90)90001-I

58. Sato K, Yabuki K, Haba T, Maekawa T. Role of Kupffer cells in the induction of tolerance after liver transplantation. J Surg Res. (1996) 63:4338. doi: 10.1006/jsre.1996.0288 
59. Callery MP, Kamei T, Flye MW. Kupffer cell blockade inhibits induction of tolerance by the portal venous route. Transplantation. (1989) 47:10924. doi: 10.1097/00007890-198906000-00041

60. Houssin D, Bellon B, Brunaud MD, Gugenheim J, Settaf A, Meriggi F, et al. Interactions between liver allografts and lymphocytotoxic alloantibodies in inbred rats. Hepatology. (1986) 6:994-8. doi: 10.1002/hep.1840060531

61. Gugenheim J, Amorosa L, Gigou M, Fabiani B, Rouger P, Gane $\mathrm{P}$, et al. Specific absorption of lymphocytotoxic alloantibodies by the liver in inbred rats. Transplantation. (1990) 50:30913. doi: 10.1097/00007890-199008000-00027

62. Chen Y, Liu Z, Liang S, Luan X, Long F, Chen J, et al. Role of Kupffer cells in the induction of tolerance of orthotopic liver transplantation in rats. Liver Transpl. (2008) 14:823-36. doi: 10.1002/lt.21450

63. Morita M, Joyce D, Miller C, Fung JJ, Lu L, Qian S. Rejection triggers liver transplant tolerance: involvement of mesenchymemediated immune control mechanisms in mice. Hepatology. (2015) 62:915-31. doi: 10.1002/hep.27909

64. Beattie L, Sawtell A, Mann J, Frame TCM, Teal B, de Labastida Rivera F, et al. Bone marrow-derived and resident liver macrophages display unique transcriptomic signatures but similar biological functions. J Hepatol. (2016) 65:758-68. doi: 10.1016/j.jhep.2016.05.037

65. Ramachandran P, Pellicoro A, Vernon MA, Boulter L, Aucott RL, Ali A, et al. Differential Ly-6C expression identifies the recruited macrophage phenotype, which orchestrates the regression of murine liver fibrosis. Proc Natl Acad Sci USA. (2012) 109:E3186-95. doi: 10.1073/pnas.1119964109

66. Banchereau J, Steinman RM. Dendritic cells and the control of immunity. Nature. (1998) 392:245-52. doi: 10.1038/32588

67. Steinman RM, Hawiger D, Nussenzweig MC. Tolerogenic dendritic cells. Annu Rev Immunol. (2003) 21:685711. doi: 10.1146/annurev.immunol.21.120601.141040

68. Merad M, Sathe P, Helft J, Miller J, Mortha A. The dendritic cell lineage: ontogeny and function of dendritic cells and their subsets in the steady state and the inflamed setting. Ann Rev Immunol. (2013) 31:563604. doi: 10.1146/annurev-immunol-020711-074950

69. Haniffa M, Collin M, Ginhoux F. Ontogeny and functional specialization of dendritic cells in human and mouse. Adv Immunol. (2013) 120:149. doi: 10.1016/B978-0-12-417028-5.00001-6

70. Steptoe RJ, Patel RK, Subbotin VM, Thomson AW. Comparative analysis of dendritic cell density and total number in commonly transplanted organs: morphometric estimation in normal mice. Transpl Immunol. (2000) 8:4956. doi: 10.1016/S0966-3274(00)00010-1

71. Creus AD, Abe M, Lau AH, Hackstein H, Raimondi G, Thomson AW. Low TLR4 expression by liver dendritic cells correlates with reduced capacity to activate allogeneic T cells in response to endotoxin. J Immunol. (2005) 174:2037-45. doi: 10.4049/jimmunol.174.4.2037

72. Biswas SK, Lopez-Collazo E. Endotoxin tolerance: new mechanisms, molecules and clinical significance. Trends Immunol. (2009) 30:47587. doi: 10.1016/j.it.2009.07.009

73. Pillarisetty VG, Shah AB, Miller G, Bleier JI, DeMatteo RP. Liver dendritic cells are less immunogenic than spleen dendritic cells because of differences in subtype composition. J Immunol. (2004) 172:100917. doi: 10.4049/jimmunol.172.2.1009

74. Bertolino P, McCaughan GW, Bowen DG. Role of primary intrahepatic T-cell activation in the "liver tolerance effect." Immunol Cell Biol. (2002). 80:84-92. doi: 10.1046/j.0818-9641.2001.01048.x

75. Thomson AW, Drakes ML, Zahorchak AF, O'Connell PJ, Steptoe RJ, Qian S, et al. Hepatic dendritic cells: immunobiology and role in liver transplantation. J Leukoc Biol. (1999) 66:322-30. doi: 10.1002/jlb.66.2.322

76. O'Connell PJ, Morelli AE, Logar AJ, Thomson AW. Phenotypic and functional characterization of mouse hepatic CD8 alpha ${ }^{+}$ lymphoid-related dendritic cells. J Immunol. (2000) 165:795803. doi: 10.4049/jimmunol.165.2.795

77. Chen Y, Jiang G, Yang HR, Gu X, Wang L, Hsieh CC, et al. Distinct response of liver myeloid dendritic cells to endotoxin is mediated by IL-27. J Hepatol. (2009) 51:510-9. doi: 10.1016/j.jhep.2009.04.026

78. Abe M, Tokita D, Raimondi G, Thomson AW. Endotoxin modulates the capacity of CpG-activated liver myeloid DC to direct Th1-type responses. Eur J Immunol. (2006) 36:2483-93. doi: 10.1002/eji.200535767
79. Khanna A, Morelli AE, Zhong C, Takayama T, Lu L, Thomson AW. Effects of liver-derived dendritic cell progenitors on Th1- and Th2-like cytokine responses in vitro and in vivo. J Immunol. (2000) 164:134654. doi: 10.4049/jimmunol.164.3.1346

80. Bamboat ZM, Stableford JA, Plitas G, Burt BM, Nguyen HM, Welles AP, et al. Human liver dendritic cells promote $\mathrm{T}$ cell hyporesponsiveness. J Immunol. (2009) 182:1901-11. doi: 10.4049/jimmunol.0803404

81. Moseman EA, Liang X, Dawson AJ, Panoskaltsis-Mortari A, Krieg AM, Liu YJ, et al. Human plasmacytoid dendritic cells activated by $\mathrm{CpG}$ oligodeoxynucleotides induce the generation of $\mathrm{CD} 4{ }^{+} \mathrm{CD} 25^{+}$regulatory $\mathrm{T}$ cells. J Immunol. (2004) 173:4433-42. doi: 10.4049/jimmunol.173.7.4433

82. Matta BM, Raimondi G, Rosborough BR, Sumpter TL, Thomson AW. IL-27 production and STAT3-dependent upregulation of $\mathrm{B} 7-\mathrm{H} 1$ mediate immune regulatory functions of liver plasmacytoid dendritic cells. J Immunol. (2012) 188:5227-37. doi: 10.4049/jimmunol.1103382

83. Ito $\mathrm{T}$, Yang $\mathrm{M}$, Wang $\mathrm{YH}$, Lande $\mathrm{R}$, Gregorio J, Perng $\mathrm{OA}$, et al. Plasmacytoid dendritic cells prime IL-10-producing $\mathrm{T}$ regulatory cells by inducible costimulator ligand. J Exp Med. (2007) 204:105-15. doi: 10.1084/jem.20061660

84. Siu JHY, Surendrakumar V, Richards JA, Pettigrew GJ. T cell allorecognition pathways in solid organ transplantation. Front Immunol. (2018) 9:2548. doi: 10.3389/fimmu.2018.02548

85. Lin CM, Gill RG. Direct and indirect allograft recognition: pathways dictating graft rejection mechanisms. Curr Opin Organ Transplant. (2016) 21:40-4. doi: 10.1097/MOT.0000000000000263

86. Yokota S, Yoshida O, Ono Y, Geller DA, Thomson AW. Liver transplantation in the mouse: insights into liver immunobiology, tissue injury, and allograft tolerance. Liver Transpl. (2016) 22:536-46. doi: 10.1002/lt.24394

87. Li W, Lu L, Wang Z, Wang L, Fung JJ, Thomson AW, et al. Il-12 antagonism enhances apoptotic death of $\mathrm{T}$ cells within hepatic allografts from Flt3 ligand-treated donors and promotes graft acceptance. J Immunol. (2001) 166:5619-28. doi: 10.4049/jimmunol.166.9.5619

88. Steptoe RJ, Fu F, Li W, Drakes ML, Lu L, Demetris AJ, et al. Augmentation of dendritic cells in murine organ donors by Flt3 ligand alters the balance between transplant tolerance and immunity. J Immunol. (1997) 159:5483-91.

89. Yoshida O, Kimura S, Dou L, Matta BM, Yokota S, Ross MA, et al. DAP12 deficiency in liver allografts results in enhanced donor DC migration, augmented effector $\mathrm{T}$ cell responses and abrogation of transplant tolerance. Am J Transplant. (2014) 14:1791-805. doi: 10.1111/ajt.12757

90. Marino J, Babiker-Mohamed MH, Crosby-Bertorini P, Paster JT, LeGuern C, Germana S, et al. Donor exosomes rather than passenger leukocytes initiate alloreactive $\mathrm{T}$ cell responses after transplantation. Sci Immunol. (2016) 1:aaf8759. doi: 10.1126/sciimmunol.aaf8759

91. Liu Q, Rojas-Canales DM, Divito SJ, Shufesky WJ, Stolz DB, Erdos G, et al. Donor dendritic cell-derived exosomes promote allograft-targeting immune response. J Clin Invest. (2016) 126:2805-20. doi: 10.1172/JCI 84577

92. Harshyne LA, Watkins SC, Gambotto A, Barratt-Boyes SM. Dendritic cells acquire antigens from live cells for cross-presentation to CTL. J Immunol. (2001) 166:3717-23. doi: 10.4049/jimmunol.166.6.3717

93. Game DS, Rogers NJ, Lechler RI. Acquisition of HLA-DR and costimulatory molecules by $\mathrm{T}$ cells from allogeneic antigen presenting cells. Am J Transplant. (2005) 5:1614-25. doi: 10.1111/j.1600-6143.2005.00916.x

94. Russo V, Zhou D, Sartirana C, Rovere P, Villa A, Rossini $S$, et al. Acquisition of intact allogeneic human leukocyte antigen molecules by human dendritic cells. Blood. (2000) 95:3473-7. doi: 10.1182/blood.V95.11.3473.011k06_3473_3477

95. Ono Y, Perez-Gutierrez A, Nakao T, Dai H, Camirand G, Yoshida O, et al. Graft-infiltrating PD-L1 high cross-dressed dendritic cells regulate antidonor $\mathrm{T}$ cell responses in mouse liver transplant tolerance. Hepatology. (2017) 67:1499-515. doi: 10.1097/01.tp.0000520343.32573.7c

96. Naranjo-Gómez M, Raïch-Regué D, Oñate C, Grau-López L, Ramo-Tello C, Pujol-Borrell R, et al. Comparative study of clinical grade human tolerogenic dendritic cells. J Transl Med. (2011) 9:89. doi: 10.1186/1479-5876-9-89

97. Penna G, Adorini L. 1 alpha,25-dihydroxyvitamin D3 inhibits differentiation, maturation, activation, and survival of dendritic cells leading to impaired alloreactive $\mathrm{T}$ cell activation. J Immunol. (2000). 164:2405-11. doi: 10.4049/jimmunol.164.5.2405 
98. Turnquist HR, Raimondi G, Zahorchak AF, Fischer RT, Wang Z, Thomson AW. Rapamycin-conditioned dendritic cells are poor stimulators of allogeneic $\mathrm{CD} 4^{+} \mathrm{T}$ cells, but enrich for antigen-specific Foxp $3^{+} \mathrm{T}$ regulatory cells and promote organ transplant tolerance. J Immunol. (2007) 178:701831. doi: 10.4049/jimmunol.178.11.7018

99. Ochando J, Ordikhani F, Jordan S, Boros P, Thomson AW. Tolerogenic dendritic cells in organ transplantation. Transpl Int. (2019) 33:11327. doi: $10.1111 /$ tri.13504

100. Rosen SJ, Harris PE, Hardy MA. State of the art: role of the dendritic cell in induction of allograft tolerance. Transplantation. (2018) 102:160313. doi: $10.1097 /$ TP. 0000000000002239

101. Thomson AW, Ezzelarab MB. Regulatory dendritic cells: profiling, targeting, and therapeutic application. Curr Opin Organ Transplant. (2018) 23:53845. doi: 10.1097/MOT.0000000000000565

102. Thomson AW, Metes DM, Ezzelarab MB, Raïch-Regué D. Regulatory dendritic cells for human organ transplantation. Transpl Rev. (2019) 33:1306. doi: 10.1016/j.trre.2019.05.001

103. Reynaert H, Thompson MG, Thomas T, Geerts A. Hepatic stellate cells: role in microcirculation and pathophysiology of portal hypertension. Gut. (2002) 50:571-81. doi: 10.1136/gut.50.4.571

104. Tsuchida T, Friedman SL. Mechanisms of hepatic stellate cell activation. Nat Rev Gastroenterol Hepatol. (2017) 14:397-411. doi: 10.1038/nrgastro.2017.38

105. Venturi C, Reding R, Quinones JA, Sokal E, Rahier J, Bueno J, et al. Relevance of activated hepatic stellate cells in predicting the development of pediatric liver allograft fibrosis. Liver Transpl. (2016) 22:822-9. doi: 10.1002/lt.24412

106. Charles R, Chou H-S, Wang L, Fung JJ, Lu L, Qian S. Human hepatic stellate cells inhibit T-cell response through B7-H1 pathway. Transplantation. (2013) 96:17-24. doi: 10.1097/TP.0b013e318294caae

107. Chinnadurai R, Grakoui A. B7-H4 mediates inhibition of T cell responses by activated murine hepatic stellate cells. Hepatology. (2010) 52:217785. doi: 10.1002/hep. 23953

108. Yu M-C, Chen C-H, Liang X, Wang L, Gandhi CR, Fung JJ, et al. Inhibition of T-cell responses by hepatic stellate cells via $\mathrm{B} 7-\mathrm{H} 1$-mediated $\mathrm{T}$-cell apoptosis in mice. Hepatology. (2004) 40:1312-21. doi: 10.1002/hep.20488

109. Schildberg FA, Wojtalla A, Siegmund SV, Endl E, Diehl L, Abdullah Z, et al. Murine hepatic stellate cells veto CD8 T cell activation by a CD54-dependent mechanism. Hepatology. (2011) 54:262-72. doi: 10.1002/hep.24352

110. Jiang Z, Chen Y, Feng X, Jiang J, Chen T, Xie H, et al. Hepatic stellate cells promote immunotolerance following orthotopic liver transplantation in rats via induction of T cell apoptosis and regulation of Th2/Th3-like cell cytokine production. Exp Ther Med. (2013) 5:165-9. doi: 10.3892/etm.2012.801

111. Sumpter TL, Dangi A, Matta BM, Huang C, Stolz DB, Vodovotz Y, et al. Hepatic stellate cells undermine the allostimulatory function of liver myeloid dendritic cells via STAT3-dependent induction of IDO. J Immunol. (2012) 189:3848-58. doi: 10.4049/jimmunol.1200819

112. Yang HR, Hsieh CC, Wang L, Fung JJ, Lu L, Qian S. A critical role of TRAIL expressed on cotransplanted hepatic stellate cells in prevention of islet allograft rejection. Microsurgery. (2010) 30:332-7. doi: 10.1002/micr.20697

113. Chen $\mathrm{CH}$, Kuo LM, Chang $\mathrm{Y}, \mathrm{Wu} \mathrm{W}$, Goldbach C, Ross MA, et al. In vivo immune modulatory activity of hepatic stellate cells in mice. Hepatology. (2006) 44:1171-81. doi: 10.1002/hep.21379

114. Chou HS, Hsieh CC, Yang HR, Wang L, Arakawa Y, Brown K, et al. Hepatic stellate cells regulate immune response by way of induction of myeloid suppressor cells in mice. Hepatology. (2011) 53:100719. doi: 10.1002/hep. 24162

115. Höchst B, Schildberg FA, Sauerborn P, Gäbel YA, Gevensleben H, Goltz D, et al. Activated human hepatic stellate cells induce myeloid derived suppressor cells from peripheral blood monocytes in a CD44dependent fashion. J Hepatol. (2013) 59:528-35. doi: 10.1016/j.jhep.2013. 04.033

116. Dunham RM, Thapa M, Velazquez VM, Elrod EJ, Denning TL, Pulendran $\mathrm{B}$, et al. Hepatic stellate cells preferentially induce Foxp $3^{+}$regulatory T cells by production of retinoic acid. J Immunol. (2013) 190:200916. doi: 10.4049/jimmunol.1201937

117. Dangi A, Sumpter TL, Kimura S, Stolz DB, Murase N, Raimondi G, et al. Selective expansion of allogeneic regulatory $\mathrm{T}$ cells by hepatic stellate cells: role of endotoxin and implications for allograft tolerance. J Immunol. (2012) 188:3667-77. doi: 10.4049/jimmunol.1102460
118. Kumar S, Wang J, Thomson AW, Gandhi CR. Hepatic stellate cells increase the immunosuppressive function of natural Foxp $3^{+}$regulatory T cells via IDO-induced AhR activation. J Leukoc Biol. (2017) 101:42938. doi: 10.1189/jlb.2A0516-239R

119. Jiang G, Yang H-R, Wang L, Wildey GM, Fung J, Qian S, et al. Hepatic stellate cells preferentially expand allogeneic $\mathrm{CD}^{+} \mathrm{CD}^{2} 5^{+} \mathrm{FoxP}^{+}$regulatory $\mathrm{T}$ cells in an IL-2-dependent manner. Transplantation. (2008) 86:1492502. doi: 10.1097/TP.0b013e31818bfd13

120. Tay SS, Lu B, Sierro F, Benseler V, McGuffog CM, Bishop GA, et al. Differential migration of passenger leukocytes and rapid deletion of naive alloreactive CD8 T cells after mouse liver transplantation. Liver Transpl. (2013) 19:1224-35. doi: 10.1002/lt.23720

121. Klugewitz K, Adams DH, Emoto M, Eulenburg K, Hamann A. The composition of intrahepatic lymphocytes: shaped by selective recruitment? Trends Immunol. (2004) 25:590-4. doi: 10.1016/j.it.2004.09.006

122. Mikulak J, Bruni E, Oriolo F, Di Vito C, Mavilio D. Hepatic natural killer cells: organ-specific sentinels of liver immune homeostasis and physiopathology. Front Immunol. (2019) 10:946. doi: 10.3389/fimmu.2019.00946

123. Zheng M, Sun H, Tian Z. Natural killer cells in liver diseases. Front Med. (2018) 12:269-79. doi: 10.1007/s11684-018-0621-4

124. Ruggeri L, Mancusi A, Capanni M, Martelli MF, Velardi A. Exploitation of alloreactive NK cells in adoptive immunotherapy of cancer. Curr Opin Immunol. (2005) 17:211-7. doi: 10.1016/j.coi.2005.01.007

125. Lanier LL. NK cell recognition. Annu Rev Immunol. (2005) 23:22574. doi: 10.1146/annurev.immunol.23.021704.115526

126. Harmon C, Sanchez-Fueyo A, O'Farrelly C, Houlihan DD. Natural killer cells and liver transplantation: orchestrators of rejection or tolerance? $\mathrm{Am}$ J Transplant. (2016) 16:751-7. doi: 10.1111/ajt.13565

127. Moroso V, Metselaar HJ, Mancham S, Tilanus HW, Eissens D, van der Meer A, et al. Liver grafts contain a unique subset of natural killer cells that are transferred into the recipient after liver transplantation. Liver Transpl. (2010) 16:895-908. doi: 10.1002/lt.22080

128. Cuff AO, Robertson FP, Stegmann KA, Pallett LJ, Maini MK, Davidson $\mathrm{BR}$, et al. Eomeshi NK cells in human liver are long-lived and do not recirculate but can be replenished from the circulation. J Immunol. (2016) 197:4283-91. doi: 10.4049/jimmunol.1601424

129. Cerboni C, Zingoni A, Cippitelli M, Piccoli M, Frati L, Santoni A. Antigenactivated human $\mathrm{T}$ lymphocytes express cell-surface NKG2D ligands via an ATM/ATR-dependent mechanism and become susceptible to autologous NK- cell lysis. Blood. (2007) 110:606-15. doi: 10.1182/blood-2006-10-052720

130. Cooper MA, Fehniger TA, Fuchs A, Colonna M, Caligiuri MA. NK cell and DC interactions. Trends Immunol. (2004) 25:47-52. doi: 10.1016/j.it.2003.10.012

131. Yu JD, Long TZ, Li GL, Lv LH, Lin HM, Huang YH, et al. Donor liver natural killer cells alleviate liver allograft acute rejection in rats. HBPD INT. (2011) 10:386-92. doi: 10.1016/S1499-3872(11)60065-9

132. Lassen MG, Lukens JR, Dolina JS, Brown MG, Hahn YS. Intrahepatic IL-10 maintains NKG2 $\mathrm{A}^{+}$Ly $49^{-}$Liver NK cells in a functionally hyporesponsive state. J Immunol. (2010) 184:2693-701. doi: 10.4049/jimmunol.0901362

133. Jamil KM, Hydes TJ, Cheent KS, Cassidy SA, Traherne JA, Jayaraman J, et al. STAT4-associated natural killer cell tolerance following liver transplantation. Gut. (2017) 66:352-61. doi: 10.1136/gutjnl-2015-309395

134. Garrod KR, Liu FC, Forrest LE, Parker I, Kang SM, Cahalan MD. NK cell patrolling and elimination of donor-derived dendritic cells favor indirect alloreactivity. J Immunol. (2010) 184:2329-36. doi: 10.4049/jimmunol.0902748

135. Rulifson IC, Szot GL, Palmer E, Bluestone JA. Inability to induce tolerance through direct antigen presentation. Am J Transplant. (2002) 2:5109. doi: $10.1034 / j .1600-6143.2002 .20604 . x$

136. Yu G, Xu X, Vu MD, Kilpatrick ED, Li XC. NK cells promote transplant tolerance by killing donor antigen-presenting cells. J Exp Med. (2006) 203:1851-8. doi: 10.1084/jem.20060603

137. Laffont S, Seillet C, Ortaldo J, Coudert JD, Guéry JC. Natural killer cells recruited into lymph nodes inhibit alloreactive T-cell activation through perforin-mediated killing of donor allogeneic dendritic cells. Blood. (2008) 112:661-71. doi: 10.1182/blood-2007-10-120089

138. Li L, Wozniak LJ, Rodder S, Heish S, Talisetti A, Wang Q, et al. A common peripheral blood gene set for diagnosis of operational tolerance in 
pediatric and adult liver transplantation. Am J Transplant. (2012) 12:121828. doi: 10.1111/j.1600-6143.2011.03928.x

139. Sarwal MM. Fingerprints of transplant tolerance suggest opportunities for immunosuppression minimization. Clin Biochem. (2016) 49:40410. doi: 10.1016/j.clinbiochem.2016.01.007

140. Margalit M, Ilan Y. Induction of immune tolerance: a role for natural killer $\mathrm{T}$ lymphocytes? Liver Int. (2005) 25:5014. doi: $10.1111 / j .1478-3231.2005 .01147 . x$

141. Morita M, Fujino M, Li XK, Kimura H, Nakayama T, Taniguchi M, et al. Spontaneous tolerance involving natural killer T cells after hepatic grafting in mice. Transpl Immunol. (2007) 18:142-5. doi: 10.1016/j.trim.2007.05.015

142. Mackay CR, Marston WL, Dudler L. Naive and memory T cells show distinct pathways of lymphocyte recirculation. J Exp Med. (1990) 171:80117. doi: $10.1084 /$ jem.171.3.801

143. Bertolino P, Bowen DG, McCaughan GW, Fazekas de St. Groth B. Antigenspecific primary activation of $\mathrm{CD}^{+} \mathrm{T}$ cells within the liver. J Immunol. (2001) 166:5430-8. doi: 10.4049/jimmunol.166.9.5430

144. Lohse A, Knolle P, Bilo K, Uhrig A, Waldmann C, Ibe M, et al. Antigen-presenting function and B7 expression of murine sinusoidal endothelial cells and kupffer cells. Gastroenterology. (1996) 110:117581. doi: 10.1053/gast.1996.v110.pm8613007

145. Mühlbauer M, Fleck M, Schütz C, Weiss T, Froh M, Blank C, et al. PD-L1 is induced in hepatocytes by viral infection and by interferon$\alpha$ and $-\gamma$ and mediates $T$ cell apoptosis. J Hepatol. (2006) 45:5208. doi: 10.1016/j.jhep.2006.05.007

146. Maier H, Isogawa M, Freeman GJ, Chisari FV. PD-1: PD-L1 interactions contribute to the functional suppression of virusspecific $\mathrm{CD}^{+} \mathrm{T}$ lymphocytes in the liver. J Immunol. (2007) 178:2714-20. doi: 10.4049/jimmunol.178.5.2714

147. De Bleser PJ, Niki T, Rogiers V, Geerts A. Transforming growth factor- $\beta$ gene expression in normal and fibrotic rat liver. J Hepatol. (1997) 26:88693. doi: 10.1016/S0168-8278(97)80257-7

148. Carambia A, Freund B, Schwinge D, Heine M, Laschtowitz A, Huber S, et al. TGF- $\beta$-dependent induction of $\mathrm{CD}^{+} \mathrm{CD}_{25} 5^{+} \mathrm{Foxp}^{+}$ Tregs by liver sinusoidal endothelial cells. $J$ Hepatol. (2014) 61:594-9. doi: 10.1016/j.jhep.2014.04.027

149. Crispe IN. Liver antigen-presenting cells. J Hepatol. (2011) 54:35765. doi: 10.1016/j.jhep.2010.10.005

150. Horst AK, Neumann K, Diehl L, Tiegs G. Modulation of liver tolerance by conventional and nonconventional antigen-presenting cells and regulatory immune cells. Cell Mol Immunol. (2016) 13:277-92. doi: $10.1038 / \mathrm{cmi} .2015 .112$

151. Mehrfeld C, Zenner S, Kornek M, Lukacs-Kornek V. The contribution of non-professional antigen-presenting cells to immunity and tolerance in the liver. Front Immunol. (2018) 9:635. doi: 10.3389/fimmu.2018. 00635

152. Crispe IN, Dao T, Klugewitz K, Mehal WZ, Metz DP. The liver as a site of T-cell apoptosis: graveyard, or killing field? Immunol Rev. (2000) 174:4762. doi: 10.1034/j.1600-0528.2002.017412.x

153. Huang L, Soldevila G, Leeker M, Flavell R, Crispe IN. The liver eliminates $\mathrm{T}$ cells undergoing antigen-triggered apoptosis in vivo. Immunity. (1994) 1:741-9. doi: 10.1016/S1074-7613(94)80016-2

154. Mehal WZ, Juedes AE, Crispe IN. Selective retention of activated $\mathrm{CD}^{+} \mathrm{T}$ cells by the normal liver. J Immunol. (1999) 163:3202-10.

155. Benseler V, Warren A, Vo M, Holz LE, Tay SS, Couteur DGL, et al. Hepatocyte entry leads to degradation of autoreactive CD8 T cells. Proc Natl Acad Sci USA. (2011) 108:16735-40. doi: 10.1073/pnas.1112251108

156. Qian S, Lu L, Fu F, Li Y, Li W, Starzl TE, et al. Apoptosis within spontaneously accepted mouse liver allografts: evidence for deletion of cytotoxic $\mathrm{T}$ cells and implications for tolerance induction. J Immunol. (1997) 158:4654-61.

157. Thai NL, Li Y, Fu F, Qian S, Demetris AJ, Duquesnoy RJ, et al. Interleukin2 and interleukin-12 mediate distinct effector mechanisms of liver allograft rejection. Liver Transpl Surg. (1997) 3:118-29. doi: 10.1002/lt.500030204

158. Clouston AD, Jonsson JR, Balderson GA, Fawcett J, Lynch SV, Kelso A, et al. Lymphocyte apoptosis and cell replacement in human liver allografts. Transplantation. (2002) 73:182834. doi: 10.1097/00007890-200206150-00022
159. McLane LM, Abdel-Hakeem MS, Wherry EJ. CD8 T cell exhaustion during chronic viral infection and cancer. Annu Rev Immunol. (2019) 37:45795. doi: 10.1146/annurev-immunol-041015-055318

160. Wherry EJ, Kurachi M. Molecular and cellular insights into T cell exhaustion. Nat Rev Immunol. (2015) 15:486-99. doi: 10.1038/nri3862

161. Hashimoto M, Kamphorst AO, Im SJ, Kissick HT, Pillai RN, Ramalingam SS, et al. CD8 $\mathrm{T}$ cell exhaustion in chronic infection and cancer: opportunities for interventions. Annu Rev Med. (2018) 69:301-18. doi: 10.1146/annurev-med-012017-043208

162. Mueller SN, Ahmed R. High antigen levels are the cause of T cell exhaustion during chronic viral infection. Proc Natl Acad Sci USA. (2009) 106:86238. doi: 10.1073/pnas.0809818106

163. Han S, Asoyan A, Rabenstein H, Nakano N, Obst R. Role of antigen persistence and dose for $\mathrm{CD} 4^{+}$T-cell exhaustion and recovery. Proc Natl Acad Sci USA. (2010) 107:20453-8. doi: 10.1073/pnas.1008437107

164. Zuniga EI, Harker JA. T cell exhaustion due to persistent antigen: quantity not quality? Eur J Immunol. (2012) 42:2285-9. doi: 10.1002/eji.201242852

165. Steger U, Denecke C, Sawitzki B, Karim M, Jones ND, Wood KJ. Exhaustive differentiation of alloreactive $\mathrm{CD}^{+} \mathrm{T}$ cells: critical for determination of graft acceptance or rejection. Transplantation. (2008) 85:1339-47. doi: 10.1097/TP.0b013e31816dd64a

166. Netea MG, Balkwill F, Chonchol M, Cominelli F, Donath MY, GiamarellosBourboulis EJ, et al. A guiding map for inflammation. Nat Immunol. (2017) 18:826-31. doi: 10.1038/ni.3790

167. Zhou L, Chong MMW, Littman DR. Plasticity of $\mathrm{CD}^{+}$ $\mathrm{T}$ cell lineage differentiation. Immunity. (2009) 30:64655. doi: 10.1016/j.immuni.2009.05.001

168. Besançon A, Baas M, Goncalves T, Valette F, Waldmann H, Chatenoud $\mathrm{L}$, et al. The induction and maintenance of transplant tolerance engages both regulatory and anergic $\mathrm{CD}^{+} \mathrm{T}$ cells. Front Immunol. (2017) 8:218. doi: 10.3389/fimmu.2017.00218

169. Burrell BE, Nakayama Y, Xu J, Brinkman CC, Bromberg JS. Treg induction, migration, and function in transplantation. J Immunol. (2012) 189:470511. doi: 10.4049/jimmunol.1202027

170. Romano M, Fanelli G, Albany CJ, Giganti G, Lombardi G. Past, present, and future of regulatory $\mathrm{T}$ cell therapy in transplantation and autoimmunity. Front Immunol. (2019) 10:43. doi: 10.3389/fimmu.2019.00043

171. Li W, Kuhr CS, Zheng XX, Carper K, Thomson AW, Reyes JD, et al. New insights into mechanisms of spontaneous liver transplant tolerance: the role of Foxp3-expressing $\mathrm{CD} 25^{+} \mathrm{CD} 4^{+}$regulatory T cells. Am J Transplant. (2008) 8:1639-51. doi: 10.1111/j.1600-6143.2008.02300.x

172. Jiang X, Morita M, Sugioka A, Harada M, Kojo S, Wakao H, et al. The importance of $\mathrm{CD} 25^{+} \mathrm{CD} 4^{+}$regulatory T cells in mouse hepatic allograft tolerance. Liver Transpl. (2006) 12:1112-8. doi: 10.1002/lt.20787

173. Davies HS, Pollard SG, Calne RY. Soluble HLA antigens in the circulation of liver graft recipients. Transplantation. (1989) 47:5247. doi: 10.1097/00007890-198903000-00025

174. Schwartz RH. Costimulation of T lymphocytes: the role of CD28, CTLA-4, and B7/BB1 in interleukin-2 production and immunotherapy. Cell. (1992) 71:1065-8. doi: 10.1016/S0092-8674(05)80055-8

175. Sumimoto R, Kamada N. Specific suppression of allograft rejection by soluble class I antigen and complexes with monoclonal antibody. Transplantation. (1990) 50:678-82. doi: 10.1097/00007890-199010000-00029

176. Geissler EK, Korzun WJ, Graeb C. Secreted donor-MHC class I antigen prolongs liver allograft survival and inhibits recipient antidonor cytotoxic T lymphocyte responses. Transplantation. (1997) 64:7826. doi: 10.1097/00007890-199709150-00024

177. Geissler EK, Graeb C, Tange S, Guba M, Jauch KW, Scherer MN. Effective use of donor MHC class I gene therapy in organ transplantation: prevention of antibody-mediated hyperacute heart allograft rejection in highly sensitized rat recipients. Hum Gene Ther. (2000) 11:45969. doi: $10.1089 / 10430340050015923$

178. Graeb C, Justl M, Scherer MN, Andrassy J, Frank E, Zuelke C, et al. Use of an adenoviral vector to express soluble donor-major histocompatibility complex molecules capable of suppressing the immune response in rat transplant recipients. Hum Immunol. (2002) 63:84452. doi: 10.1016/S0198-8859(02)00460-3 
179. Qian S, Fu F, Li Y, Lu L, Rao AS, Starzl TE, et al. Impact of donor MHC class I or class II antigen deficiency on first- and second-set rejection of mouse heart or liver allografts. Immunology. (1996) 88:1249. doi: 10.1046/j.1365-2567.1996.d01-633.x

180. Spencer SC, Fabre JW. Water-soluble form of RT1.A class I MHC molecules in the kidney and liver of the rat. Immunogenetics. (1987) 25:918. doi: $10.1007 / \mathrm{BF} 00364273$

181. Hausmann R, Zavazava N, Steinmann J, Müller-Ruchholtz W. Interaction of papain-digested HLA class I molecules with human alloreactive cytotoxic T lymphocytes (CTL). Clin Exp Immunol. (1993) 91:1838. doi: 10.1111/j.1365-2249.1993.tb03376.x

182. Gansuvd B, Hagihara M, Munkhbat B, Kanai N, Morita N, Munkhtuvshin $\mathrm{N}$, et al. Inhibition of Epstein-Barr virus (EBV)-specific $\mathrm{CD}^{+}$cytotoxic $\mathrm{T}$ lymphocyte (CTL) activity by soluble HLA class I in vitro. Clin Exp Immunol. (2000) 119:107-14. doi: 10.1046/j.1365-2249.2000.01092.x

183. Behrens D, Lange K, Fried A, Yoo-Ott KA, Richter K, Fändrich F, et al. Donor-derived soluble MHC antigens plus low-dose cyclosporine induce transplantation unresponsiveness independent of the thymus by down-regulating $\mathrm{T}$ cell-mediated alloresponses in a rat transplantation model. Transplantation. (2001) 72:197482. doi: 10.1097/00007890-200112270-00018

184. Semiletova NV, Shen XD, Feldman DM, Busuttil RW, Kupiec-Weglinski JW, Ghobrial RM. Donor MHC class I peptides in conjunction with selfepitopes induce donor-specific tolerance in a dose-dependent manner but unable to abrogate chronic rejection. Transplant Proc. (2005) 37:19379. doi: 10.1016/j.transproceed.2005.02.114

185. Doenecke A, Frank E, Scherer MN, Schlitt HJ, Geissler EK. Prolongation of heart allograft survival after long-term expression of soluble MHC class I antigens and vIL-10 in the liver by AAV-plasmid-mediated gene transfer. Langenbecks Arch Surg. (2008) 393:343-8. doi: 10.1007/s00423-008-0298-2

186. Porto JD, Johansen TE, Catipović B, Parfiit DJ, Tuveson D, Gether U, et al. A soluble divalent class I major histocompatibility complex molecule inhibits alloreactive T cells at nanomolar concentrations. Proc Natl Acad Sci USA. (1993) 90:6671-5. doi: 10.1073/pnas.90.14.6671

187. O’Herrin SM, Slansky JE, Tang Q, Markiewicz MA, Gajewski TF, Pardoll DM, et al. Antigen-Specific blockade of t cells in vivo using dimeric mhe peptide. J Immunol. (2001) 167:2555-60. doi: 10.4049/jimmunol.167.5.2555

188. Fried A, Berg M, Sharma B, Bonde S, Zavazava N. Recombinant dimeric MHC antigens protect cardiac allografts from rejection and visualize alloreactive $\mathrm{T}$ cells. J Leukocyte Biol. (2005) 78:595-604. doi: 10.1189/jlb.0205078

189. Schlitt HJ, Kanehiro H, Raddatz G, Steinhoff G, Richter $\mathrm{N}$, Nashan B, et al. Persistence of donor lymphocytes in liver allograft recipients. Transplantation. (1993) 56:10017. doi: 10.1097/00007890-199310000-00042

190. Starzl TE, Demetris AJ, Trucco M, Murase N, Ricordi C, Ildstad $\mathrm{S}$, et al. Cell migration and chimerism after whole-organ transplantation: the basis of graft acceptance. Hepatology. (1993) 17:1127-52. doi: 10.1002/hep.1840170629

191. Starzl TE, Demetris AJ, Trucco M, Ramos H, Zeevi A, Rudert WA, et al. Systemic chimerism in human female recipients of male livers. Lancet. (1992) 340:876-7. doi: 10.1016/0140-6736(92)93286-V

192. Hammond EJ, Ng RL, Stanley MA, Munro AJ. Prolonged survival of cultured keratinocyte allografts in the nonimmunosuppressed mouse. Transplantation. (1987) 44:10612. doi: 10.1097/00007890-198707000-00022

193. Stone JP, Critchley WR, Major T, Rajan G, Risnes I, Scott H, et al. Altered immunogenicity of donor lungs via removal of passenger leukocytes using ex vivo lung perfusion. Am J Transplant. (2016) 16:3343. doi: 10.1111/ajt.13446

194. Brown K, Nowocin AK, Meader L, Edwards LA, Smith RA, Wong W. Immunotoxin against a donor mhc class ii molecule induces indefinite survival of murine kidney allografts. Am J Transplant. (2016) 16:112938. doi: 10.1111/ajt.13584

195. Bishop GA, Sun J, DeCruz DJ, Rokahr KL, Sedgwick JD, Sheil AG, et al. Tolerance to rat liver allografts. III. Donor cell migration and toleranceassociated cytokine production in peripheral lymphoid tissues. J Immunol. (1996) 156:4925-31.
196. Sun J, McCaughan GW, Gallagher ND, Sheil AG, Bishop GA. Deletion of spontaneous rat liver allograft acceptance by donor irradiation. Transplantation. (1995) 60:233-6. doi: 10.1097/00007890-199508000-00004

197. Shimizu Y, Goto S, Lord R, Vari F, Edwards-Smith C, Chiba $S$, et al. Restoration of tolerance to rat hepatic allografts by spleen-derived passenger leukocytes. Transpl Int. (1996) 9:593-5. doi: 10.1111/j.1432-2277.1996.tb00920.x

198. Sun J, Sheil AG, Wang C, Wang L, Rokahr K, Sharland A, et al. Tolerance to rat liver allografts: IV. Acceptance depends on the quantity of donor tissue and on donor leukocytes. Transplantation. (1996) 62:172530. doi: 10.1097/00007890-199612270-00005

199. Sharland A, Yan Y, Wang C, Bowen DG, Sun J, Sheil AG, et al. Evidence that apoptosis of activated $\mathrm{T}$ cells occurs in spontaneous tolerance of liver allografts and is blocked by manipulations which break tolerance. Transplantation. (1999) 68:1736-45. doi: 10.1097/00007890-199912150-00018

200. Devlin J, Doherty D, Thomson L, Wong T, Donaldson P, Portmann $\mathrm{B}$, et al. Defining the outcome of immunosuppression withdrawal after liver transplantation. Hepatology. (1998) 27:926-33. doi: 10.1002/hep.5102 70406

201. Girlanda R, Rela M, Williams R, O'Grady JG, Heaton ND. Long-term outcome of immunosuppression withdrawal after liver transplantation. Transplant Proc. (2005) 37:1708-9. doi: 10.1016/j.transproceed.2005.03.070

202. Wood K, Sachs DH. Chimerism and transplantation tolerance: cause and effect. Immunol Today. (1996) 17:5847. doi: 10.1016/S0167-5699(96)10069-4

203. Zanella G, Reif AE, Buenviaje OL, Asakuma R, Deterling RAJ. On prolonged survival of massive skin allografts in mice. Transplantation. (1968) 6:88594. doi: 10.1097/00007890-196811000-00003

204. Lappé MA, Graff RG, Snell GD. The importance of target size in the destruction of skin grafts with non-H-2 incompatibility. Transplantation. (1969) 7:372-7. doi: 10.1097/00007890-19690500000006

205. Wang C, Sheil AGR, Sun J. Outcome of different models of multiorgan transplantation in rats. Microsurgery. (1999) 19:31823. doi: 10.1002/(SICI)1098-2752-1999-19:7<318::AID-MICR5>3.0.CO;2-P

206. Dirsch O, Li J, He Q, Ji Y, Gu YL, Dahmen U. Induction of rejection after small-for-size liver transplantation: size matters. J Invest Surg. (2008) 21:288-98. doi: 10.1080/08941930802216823

207. Yang ZF, Ho DWY, Chu ACY, Wang YQ, Fan ST. Linking inflammation to acute rejection in small-for-size liver allografts: the potential role of early macrophage activation. Am J Transplant. (2004) 4:196-209. doi: 10.1046/j.1600-6143.2003. 00313.x

208. Shiraishi M, Csete ME, Yasunaga C, Drazan KE, Jurim O, Cramer DV, et al. Regeneration-induced accelerated rejection in reduced-size liver grafts. Transplantation. (1994) 57:33640. doi: 10.1097/00007890-199402150-00004

209. Bishop GA, Sun J, Sheil AG, McCaughan GW. High-dose/activationassociated tolerance: a mechanism for allograft tolerance. Transplantation. (1997) 64:1377-82. doi: 10.1097/00007890-19971127000001

210. Fong TL, Bunnapradist S, Jordan SC, Selby RR, Cho YW. Analysis of the united network for organ sharing database comparing renal allografts and patient survival in combined liver-kidney transplantation with the contralateral allografts in kidney alone or kidney-pancreas transplantation. Transplantation. (2003) 76:348-53. doi: 10.1097/01.TP.0000071204.03720.BB

211. He C, Schenk S, Zhang Q, Valujskikh A, Bayer J, Fairchild RL, et al. Effects of $\mathrm{T}$ cell frequency and graft size on transplant outcome in mice. J Immunol. (2004) 172:240-7. doi: 10.4049/jimmunol.172.1.240

212. Ganbold A, Andersen S, Tay SS, Cunningham E, Ilie V, Krishnan S, et al. Expression of common gamma chain signalling cytokines and their receptors distinguishes rejection from tolerance in a rat organ transplant model. Transplant Immunol. (2012) 27:89-94. doi: 10.1016/j.trim.2012. 08.001

213. Tay SS, Wong YC, McDonald DM, Wood NAW, Roediger B, Sierro F, et al. Antigen expression level threshold tunes the fate of CD8 T cells 
during primary hepatic immune responses. Proc Natl Acad Sci USA. (2014) 111:E2540-9. doi: 10.1073/pnas.1406674111

Conflict of Interest: The authors declare that the research was conducted in the absence of any commercial or financial relationships that could be construed as a potential conflict of interest.
Copyright (C) 2020 Jiang, Que, Zhu and Li. This is an open-access article distributed under the terms of the Creative Commons Attribution License (CC BY). The use, distribution or reproduction in other forums is permitted, provided the original author(s) and the copyright owner(s) are credited and that the original publication in this journal is cited, in accordance with accepted academic practice. No use, distribution or reproduction is permitted which does not comply with these terms. 